NOTICE has been reproduced from the best availajie $\quad$ LA -10023 apility.

DEB4 015073

\title{
Helium Release from Radioisotopic Heat Sources
}

\author{
D. E. Peterson \\ J. W. Early \\ J. S. Starzynski* \\ C. C. Land
}

DISCLAIMER

\begin{abstract}
This report was prepared as an account of work sponsored by an agency of the United States Government. Neither thc United States Government nor any agency thereof, nor any of their employees, makes any warranty, express or implied, or assumes any legal iiability or responsibility for th: accuracy, completeness, or usefulness of any information, apparatus, product, or process disclosed, or represents that its use would not infringe privately owned rights. Reference herein to any specific commercial product, process. or service by trade name, trademark, manufacturer, or otherwise does not necessarily constitute or imply its endorsement, reoommendation, or favoring by the United States Government or any agency thereof. The views and opinions of authors expressed herein do not necessarily state or reflect those of the United States Government or any agency thereof.
\end{abstract}

-Department of Chemistry. University of California at Santa Cruz, Santa Cruz, CA 96064.

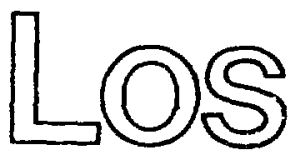

$\Delta$ 


\title{
HELI' RELEASE FROM RADIOISOTOPIC HEAT SOURCES
}

by

\author{
D. E. Peterson, J. W. Early, J. S. Starzynski, and C. C. Land
}

\begin{abstract}
Diffusion of helium in ${ }^{238} \mathrm{PuO}_{2}$ fuel was characterized as a function of the heating rate and the fuel microstricture. The samples were therinally ramped in an induction furnace and the helium release rates measured with an automated mass spectrc aeter. The diffusion constants and activation energies were obrained from the data using a simple diffusion model. The release rates of helium vere currelated with the fuel microstructure by metallographic examination of fuel samples. The release mechanism consists of four regimes, which are dependent upon the temperature. Initially, the release is controlled by nove nent of point defects combined with trapping along grair boundaries. This regime is followed by a process dominated by formation and growth of helium bubbles 2.ong grain boundaries. The third regime involves volume diffusion controlled by movement of oxygen vacancies. Finally, the release at the highest temperatures follows the diffusion rate of intragranular bubbles. The tendency for helium to be trapped within the grain boundaries diminishes with small grain sizes, slow thermal pulses, and older fuel. Activation energies and diffusion constants were correlated with previous measurements conducted on inert gases diffusing in ceramics. The helium release measured from a Light-Weight Radioisotopic Heater Unit in an earlier study was yerified, and the release behavior was predicted for a heat source containing the curren: fuel form.
\end{abstract}

\section{INTRODUCTION}

Among the phenomena associated with application of nuclear fuels, none has so frustrated the designer, challenged the experimentaiist, or intrigued the theorist as the behavior of gases internally generated by the fuels. Concern over the diffusion and release of the fission gases xenon and krypton dates from the late 1950s. Even though numerous experiments have been performed on the gas release behavior of nuclear fuels, no comprehensive model has yet been developed.

Many of the complexities that have prevented complete interpretation of this phenomenon are also evident in analyzing the diffusion of helium within the plutonia fuel used as the heat source in the radiorsotopic thermoelectric generatoss (RTGs) that provide electrical power for spacecraft used for deep-space missions. The RTGs have powered spacecraft since 1961, most recently in the Voyager missions to Jupiter and Saiurn. The next scheduled uses are the Galileo Jupiter orbiter/probe and the International Solar-Polar mission. ${ }^{1}$

Briefly, the heat source consists of a ${ }^{239} \mathrm{FuO}_{2}$ fuei cylindrical pellet encapsulated ir. a vented noble-metal clad and is surrounded by various protective layers that mitigate the thermal and mechanical effects of accident environments. The heaf source can be used to provide local heat to a spacecraft component or to gerserate elestricity using thermoelectric conversion. The two heat sources of concern to us are the General Purpose lieat Source (GPHS), a modular heat source designed at i-os 
Alarnos for use in the thermoelectric systems, and the Light-Weight Radioisotopic Heater Unit (LWRHU), a I-W thermal source designed at Los Alamos for the Galileo mission.

Decay of the ${ }^{238} \mathrm{Pu}$ isotope produces an alpha particle, which is a helium ion; hence, the fuel is contınually generating helium gas. Even though the solubility of helium within the $\mathrm{PuO}_{2}$ lattice is relatively low, the gas is trapped within the structure at ambient temperatures. The helium contained within an aged fuei is released upon increasing the tenuperature above $900^{\circ} \mathrm{C}$ under operational conditions or during an accidental reentry into the Earth's atmosphere.

The helium generated in the fuel and the details of its movement through and release from the riel are of interest for several reasons. It can modify the fuel's microstructure and microstructure-dependent properties, it controls the flow requirements for the capsule vents, and the release of helium to the heat source structure can affect its temperature distribution.

Previous measurements of the helium release rates from GPHS and LWRHU capsules have becn reported. ${ }^{2,3}$ These studies were limited to tests of individual fuel capsules. In the current work, these experiments were extended to include the examination of the effects on the helium release of varying the fuel microstructure and thermal ramp. The conclusions drawn from this study can be applied to analyses of the release behavior of the helium from the actual GPHS and LWRHU systems subjected to various operating and reentry conditions. Similar predictions based on the results of this work could also be applicable to reactor fuels and nuclear waste forms.

\section{EXPERIMENTAL APPROACH}

Most of the plutonia samples employed in this study were from the GPHS fuel pellet GP-19. This fuel pellet was made from a mixture of high-fired and low-fired shards. The pellet was hot-pressed and sintered at Los Alamos on March 14 and 19, 1979, respectively. A description of the fabrication conditions has been previously published by Kent. ${ }^{4}$ The pellet had an overall density of $84.4 \%$ and an isotopic composition of $80 \mathrm{wt} \%$ ${ }^{238} \mathrm{Pu}$ with the rest being ${ }^{239} \mathrm{Pu}$. The capsule assembly, IRG-62, was fueled with GP-19 and welded on October 22,1980 . A preentry heat treatment of the assembly was conducted at a clad temperature of $1133^{\circ} \mathrm{C}$ for 5 days. This was followed by a simulated reentry pulse in which the clad temperature was iricreased to $1567^{\circ} \mathrm{C}$ in $4 \mathrm{~min}$. The experimental details and helium release studies conducted during these heat treatinents have been reported by Peterson and Frantz. ${ }^{2}$

The general features of the apparatus used to obtain the helium release measurements have been described in detail by Early and Abernathey. ${ }^{5}$ Each plutonia sample vas placed in a tantalum or tungsten cup and the systerm evacuated. Selected temperature ramps were obtained by use of a programmed induction heater. A quadrupole mass spectrometer connected to a minicompute- enabled measurement of the helium release rates as a function of time and temporature. The spectrometer was calibrated by bleeding known flow rates of helium into the instrument and measuring the corresponding ${ }^{4} \mathrm{He}^{+}$intensity.

The sample temperture history for a given thermal pulse was determined in a separate experiment. A graphite cell was subjected to the same programmed thermal pulse to which a sample was exposed. A Leeds and Northup* automatic pyrometer sighted on a blackbody in the graphite cell was used to determine the temperature as a function of time for any given pulse. The pyrometer had been previously calibrated against a $\mathrm{Na}$ tional Bureau of Standards lamp. Corrections for the absorption of the sight glass and glove box window were applied to the measured temperatures.

Samples cut from the GPHS pellet GP-19 were exposed to thermal ramps ranging from 12 to $454^{\circ} \mathrm{C} / \mathrm{min}$. Sample sizes were kept small to mimimize temperature errors caused by self-heating of the ${ }^{238} \mathrm{Pu}$, thermal conductivity differences in the graphite calibrant and the plutonia, and changes in their total heat capacities. A Digital Equipment Corporation ${ }^{* *}$ MiNC-i 1 minicomputer was used to analyze the experimental helium release rates to obtain diffusion constants and activation energies.

Additional samples with different microstructures ind helium inventories were also examined in this series of experiments. Three fuel pellets (14367) that were $8.6 \mathrm{yr}$ old and that weighed $1.079 \mathrm{~g}$ each were subjected to a thermal ramp of $10^{\circ} \mathrm{C} / \mathrm{min}$ during which the helium release rates were measured. Helium release from a pellet (17914-1) fabricated at Savannah River Laboratory (SRL) was also determined during a thermal ramp at $31^{\circ} \mathrm{C} / \mathrm{min}$. Tile microstructures of fractions of one of the

\footnotetext{
*Leeds and Northrup, Lid., 4907 Stenton Ave., Philadelphia. Pennsylvania.

*Digital Equipment Corporation, 146 Main St., Maynard. MA 01754.
} 
8.6-yr-old pellets (14367-1) and of the SRL pellet were also examined metallographically.

\section{THEORETICAL ANALYSIS}

The rates of helium release measured in this study were modeled based on Fick's first law of simple diffusion,

$P=-D \frac{d C}{d X}$,

where $P$ is the gaseous flux,

$\mathrm{D}$ is the diffusion constant, and

$\frac{d C}{d X}$ is the concentration gradient.

Assuming that the diffusion is spherically symmetrical and that the radius of the releasing unit is a; we may derive the relationship, ${ }^{7}$

$F=1-\frac{6}{\pi^{2}} \sum_{n=1}^{\infty} \frac{1}{n^{2}} \exp \left(-n^{2} \pi^{2} D t / a^{2}\right)$,

where $F$ is the fractional release, or the helium released at time $\mathrm{t}$ divided by the total amount initially present. Because the radius parameter a is difficult to obtain, the effective diffusion constant $D^{\prime}$, equivalent to $D / a^{2}$, is usec in this study.

For the case in which $\mathrm{D}^{\prime}$ varies with time, a parameter $t$ is defined as

$\tau=\int_{0}^{t} D^{\prime} d t$

It can be shown that $\tau$ simply replaces the $\mathrm{Dt} / \mathrm{a}^{2}$ term in Eq. (2).

Then, use of the approximation derived by Sung and Turnbaugh $^{8}$ gives

$$
\begin{gathered}
F=6\left(\frac{\tau}{\pi}\right)^{1 / 2}-3 \tau \\
\text { for } \tau \leq 0.07 .
\end{gathered}
$$

For $\tau>0.07$, the following approximation is applicable:

$$
F=1-\frac{6}{\pi^{2}} \sum_{n=1}^{4} \frac{1}{n^{2}} \exp \left(-n^{2} \pi^{2} \tau\right)
$$

The measured fraction, released as a function of time and temperature, was used in Eqs. (4) and (5) to obtain $\tau$ and therefore $D^{\prime}$. The Newton-Raphson method ${ }^{9}$ of successive approximations was used to solve Eq. (5) for $\tau$.

The simple diffusion mode ${ }^{10}$ involving an interstitial diffusion mechanism would be expected to have a diffusion constant with a temperature dependerice of the form

$D^{\prime}=D_{0}^{\prime} \exp \left(-E_{\mathrm{a}} / R T\right)$,

where $E_{a}$ is the activation energy, $D_{0}^{\prime}$ is the effective constant for diffusion, $R$ is the gas constant, and $T$ is the temperature $(K)$. Linear least squares analysis of each plot of $\log D^{\prime}$ vs $1 / T$ yields an $E_{a}$ value from the slope and a $\log D_{0}^{\prime}$ value from the intercept.

We used the following equation, based on the decay rate and pellet weight, to calculate the helium level generated by alpha decay in each plutonia sample:

$\mathrm{V}_{\mathrm{He}}\left[\mathrm{cm}^{3}(\mathrm{STP})\right]=0.8296[1-\exp (-0.0079 t)](\mathrm{G})(\mathrm{E})$,

where $t$ is the time (yr), $G$ is the pellet weight $(g)$, and $E$ is the isotopic enrichment factor $\left(80 \%{ }^{238} \mathrm{Pu}\right)$. Any contribution to the helium inventory of the samples caused by the decay of ${ }^{239} \mathrm{Pu}$ was negligible since the half-life factor $\left({ }^{239} \mathrm{Pu} /{ }^{238} \mathrm{Pu}\right)$ is $\sim 270$.

\section{RESULTS}

\section{A. Sample Parameters}

Parameters associated with ${ }^{238} \mathrm{PuO}_{2}$ samples exposed to thermal ramps in this study are summarized in Table 1 . The first two columns list the thermal ramp and the run number, respectively. The remaining columns show the sam;le mass, age, and percentage of helium released during each run [relative to the inventory calculated from Eq. (7)]. An isothermal heat treatment $\left(1600^{\circ} \mathrm{C}\right.$ until the helium intensity dropped to background) followed each thermal ramp. No trends were observabie between the total helium released during a run and the associated temperature ramp or the mass and age of a sample, although the percentage released varied from 74.7 to $100 \%$. 
TABLE 1. Experimental Parameters Associated with Helium Relcuse Measurements Conducted on ${ }^{238}$ PuC $_{2}$ Samples Exposed to Thermal Pulses

\begin{tabular}{|c|c|c|c|c|c|c|c|c|c|}
\hline $\begin{array}{c}\text { Ramp } \\
\left({ }^{\circ} \mathrm{C} / \mathrm{min}\right)\end{array}$ & $\begin{array}{l}\text { Run } \\
\text { No. }\end{array}$ & $\begin{array}{c}\text { Mass } \\
\text { (g) }\end{array}$ & $\begin{array}{l}\text { Age } \\
\text { (yr) }\end{array}$ & $\begin{array}{c}\text { Release } \\
(\%)\end{array}$ & $\begin{array}{c}\text { Ramp } \\
\left({ }^{\circ} \mathrm{C} / \mathrm{min}\right)\end{array}$ & $\begin{array}{l}\text { Run } \\
\text { No. }\end{array}$ & $\begin{array}{c}\text { Mass } \\
\text { (g) }\end{array}$ & $\begin{array}{l}\text { Age } \\
\text { (yr) }\end{array}$ & $\begin{array}{c}\text { Release } \\
\text { (\%) }\end{array}$ \\
\hline \multirow[t]{3}{*}{454} & 16 & 0.103 & 0.518 & 83.0 & 227 & 33 & 0.492 & 0.608 & 82.7 \\
\hline & 37 & 0.115 & 0.652 & 91.8 & & 36 & 0.156 & 0.652 & 90.6 \\
\hline & 39 & 0.198 & 0.668 & 90.2 & & 38 & 0.253 & 0.663 & 86.8 \\
\hline \multirow[t]{6}{*}{240} & 47 & 0.745 & 0.784 & 94.9 & & 40 & 0.744 & 0.707 & 83.1 \\
\hline & 49 & 0.554 & 0.797 & 92.4 & 148 & 5 & 0.579 & 0.390 & 77.9 \\
\hline & 50 & 0.805 & 0.816 & 100 & & 9 & 0.756 & 0.403 & 87.7 \\
\hline & 53 & 0.531 & 1.268 & 87.3 & & 10 & 0.321 & 0.441 & 91.4 \\
\hline & 56 & 0.218 & 1.285 & 82.7 & 122 & 43 & 0.835 & 0.764 & 91.9 \\
\hline & 57 & 0.195 & 1.288 & 82.0 & & 45 & 1.100 & 0.770 & 94.7 \\
\hline \multirow[t]{14}{*}{227} & 17 & 0.200 & 0.520 & 100 & & 46 & 0.696 & 0.781 & 89.7 \\
\hline & 18 & 0.169 & 0.529 & 87.4 & & 51 & 0.815 & 1.189 & 74.7 \\
\hline & 19 & 0.255 & 0.532 & 90.2 & & 52 & 0.797 & 1.189 & 85.3 \\
\hline & 20 & 0.236 & 0.532 & 89.4 & & 54 & 0.357 & 1.279 & 83.5 \\
\hline & 21 & 0.231 & 0.534 & 88.8 & & 55 & 0.412 & 1.282 & 85.2 \\
\hline & 23 & 0.118 & 0.537 & 90.8 & 53.3 & 58 & 0.122 & 1.301 & 87.9 \\
\hline & 24 & 0.116 & 0.551 & 94.0 & & 59 & 0.126 & 1.304 & 80.6 \\
\hline & 25 & 0.115 & 0.553 & 90.9 & 31.0 & 66 & 0.120 & 1.334 & 91.0 \\
\hline & 26 & 0.368 & 0.553 & 91.6 & 26.6 & 60 & 0.815 & 1.318 & 79.6 \\
\hline & 28 & $0.2^{2+7}$ & 0.567 & 89.0 & & 61 & 0.310 & 1.320 & 83.9 \\
\hline & 29 & 0.406 & 0.570 & 93.2 & & 62 & 0.135 & 1.320 & 88.1 \\
\hline & 30 & 0.450 & 0.570 & 94.2 & 12.0 & 63 & 1.235 & 1.323 & 96.1 \\
\hline & 31 & 0.476 & 0.597 & 95.4 & & 64 & 0.891 & 1.326 & 95.1 \\
\hline & 32 & 0.599 & 0.605 & 96.1 & & 65 & 0.134 & 1.334 & 89.2 \\
\hline
\end{tabular}

\section{B. Temperature Dependerrce of Diffusion Constants}

The helium release rates measured in this study were analyzed as described in Sec. III to obtain $D^{\prime}$ as a function of time and temperature. Plots of $\log D^{\prime}$ vs $1 / T$ revealed breaks that occurred at approximately the same temperature for all the samples. Values of $\mathrm{E}_{\mathrm{a}}$ and $\log \mathrm{D}_{0}^{\prime}$ together with their associated standard deviations are given in Table II for the 18 plutonia samples exposed to a $227^{\circ} \mathrm{C} / \mathrm{min}$ temperature ramp. These parameters were obtained by performing least squares analyses over definite temperature ranges where each plot arpeared to be linear. There were definite break points at the approximate temperatures $640,885,1170$, and $1380^{\circ} \mathrm{C}$. Averages in the parameters over each temperature range are also given; they were used in generating the $\log D^{\prime}$ vs $1 / T$ plot shown in Fig. 1. The spread in the $\log D^{\prime}$ values is shown for each region with the largest deviation associated with the lowest temperatures. Certain values were excluded from the averages because of their large deviations from the mean. The temperature dependence of the average diffusion constant was used to calculate the time and temperature dependence of the helium release fraction. This calculated fraction is plotted as a function of time and temperature in Fig. 2. The corresponding fractional release behavior measured in runs $25,29,38$, and 40 with an associated ramp of $227^{\circ} \mathrm{C} / \mathrm{min}$ was selected for comparison. Less than $10 \%$ of the helium inventory was released during these ramps.

Additional plutonia sampies were exposed to faster pulses of 454 and $240^{\circ} \mathrm{C} / \mathrm{min}$. Plots of $\log \mathrm{D}^{\prime}$ vs $1 / \mathrm{T}$ for these runs are shown in Figs. 3 ard 4, respectively. The average results from the $227^{\circ} \mathrm{C} / \mathrm{min}$ pulse are also displayed for comparison. In each case there are breaks in the plot of $\log D^{\prime}$ vs $1 / T$. Similarities are evident in the $\mathrm{E}_{\mathrm{a}}$ and $\log \mathrm{D}_{0}^{\prime}$ values shown in Table III.

Plutonia samples were also exposed to slower thermal ramps of $148,120,53.3,26.6$, and $12.0^{\circ} \mathrm{C} / \mathrm{min}$. Plots of $\log D^{\prime}$ vs $1 / T$ determined from analyses of the measured helium release rates ciuring these ramps are shown in Figs $5-8$. The averaged results from the $227^{\circ} \mathrm{C} / \mathrm{min}$ ramp are also shown for comparison. Here the low-and 


\begin{tabular}{|c|c|c|c|c|c|c|c|c|}
\hline \multirow{2}{*}{$\begin{array}{l}\text { Run } \\
\text { No. }\end{array}$} & \multicolumn{2}{|c|}{$\begin{array}{c}\text { Low Temperature } \\
\left(640-885^{\circ} \mathrm{C}\right)\end{array}$} & \multicolumn{2}{|c|}{$\begin{array}{l}\text { Meciium Temperature } \\
\left(885-1170^{\circ} \mathrm{C}\right)\end{array}$} & \multicolumn{2}{|c|}{$\begin{array}{l}\text { High Temperature } \\
\left(1170-1380^{\circ} \mathrm{C}\right)\end{array}$} & \multicolumn{2}{|c|}{$\begin{array}{l}\text { Very High Temperature } \\
\left(1380-1660^{\circ} \mathrm{C}\right)\end{array}$} \\
\hline & $E_{1}$ & $\log D_{0}^{\prime}$ & E. & $\log U_{0}^{\prime}$ & $\mathrm{E}_{\mathbf{1}}$ & $\log D_{0}^{\prime}$ & $\mathbf{E}_{2}$ & $\log D_{0}^{\prime}$ \\
\hline 17 & $28.0 \pm 1.6^{\circ}$ & $-4.358 \pm 0.384^{\prime}$ & $79.0 \pm 3.6^{4}$ & $5.504+0.618^{2}$ & $48.1 \pm 1.5^{a}$ & $0.678 \pm 0.207^{\prime}$ & $\cdots$ & $\cdots$ \\
\hline 18 & $17.6 \pm 0.4^{\prime \prime}$ & $-5.398 \pm 0.094^{2}$ & $65.1 \pm 1.1^{n}$ & $3.720 \pm 0.187^{\circ}$ & $52.5 \pm 2.5$ & $1.525+5.342$ & $\cdots$ & $\cdots$ \\
\hline 19 & $22.4 \pm 2.8$ & $-4.282 \pm 0.567$ & $\ldots$ &.- & $53.3 \pm 1.6$ & $1.627 \pm 0.222$ & -.. & $\cdots$ \\
\hline 20 & $23.3 \pm 1.8$ & $-5.725 \pm 0.442$ & $89.9 \pm 4.0$ & $6.946 \pm 0.670$ & $52.8 \pm 1.8$ & $1.339 \pm 0.246$ & -.. & $\ldots$ \\
\hline 21 & $25.6 \pm 2.8$ & $-3.504 \pm 0.643$ & $\ldots$ & $\ldots$ & $52.6 \pm 2.4$ & $2.073 \pm 0.346$ & $146 \pm 9$ & $14.13 \pm 1.12$ \\
\hline 23 & $27.0 \pm 1.4$ & $-4.541 \pm 0.310$ & $91.7 \pm 2.1$ & $7.668 \pm 0.359$ & $52.8 \pm 3.6$ & $1.691 \pm 0.499$ & $\ldots$ &.-- \\
\hline 24 & $26.3 \pm 0.5$ & $-4.106 \pm 0.114$ & $91.1 \pm 1.0$ & $7.724 \pm 0.166$ & $52.1 \pm 1.3$ & $1.712 \pm 0.191$ & $144 \pm 12$ & $13.63 \pm 1.50$ \\
\hline 25 & $23.5 \pm 1.4$ & $-4.495 \pm 0.320$ & $65.7 \pm 2.3^{\circ}$ & $3.804 \pm 0.395^{\star}$ & $44.7 \pm 1.4^{\mathrm{a}}$ & $0.457 \pm 0.194^{\natural}$ & $162 \pm 12^{n}$ & $15.30 \pm 1.51^{*}$ \\
\hline 26 & $23.9 \pm 1.7$ & $-5.392 \pm 0.375$ & $97.5 \pm 3.6$ & $8.332 \pm 0.602$ & $52.9 \pm 1.2$ & $1.413 \pm 0.163$ & ... & -.. \\
\hline 28 & $22.2 \pm 0.4$ & $-5.184 \pm 0.102$ & $92.0 \pm 3.1$ & $7.405 \pm 0.498$ & $56.4 \pm 2.3$ & $2.15: \pm 0.316$ & -- & -.- \\
\hline 29 & $24.2 \pm 1.6$ & $-5.047 \pm 0.395$ & $90.9 \pm 3.8$ & $7.540 \pm 0.628$ & $52.0 \pm 1.5$ & $1.603 \pm 0.211$ & $140 \pm 10$ & $13.02 \pm 1.29$ \\
\hline 30 & $21.6 \pm 0.5$ & $-5.736 \pm 0.11 ?$ & $89.3 \pm 4.2$ & $6.888 \pm 0.663$ & $51.9 \pm 2.1$ & $1.325 \pm 0.294$ & --- & --- \\
\hline 31 & $24.5 \pm 0.3$ & $-5.893 \pm 0.080$ & $92.6 \pm 4.0$ & $7.132 \pm 0.661$ & $50.3 \pm 2.5$ & $0.917 \pm 0.353$ & $\ldots$ & $\ldots$ \\
\hline 32 & $24.7 \pm 2.0$ & $-5.257 \pm 0.472$ & $91.1 \pm 4.0$ & $7.045 \pm 0.648$ & $54.6 \pm 2.2$ & $1.544 \pm 0.299$ & $\ldots$ & $\cdots$ \\
\hline 33 & $32.1 \pm 0.1^{a}$ & $-3.899 \pm 0.028^{8}$ & $93.9 \pm 3.8$ & $8.043 \pm 0.677$ & $52.3 \pm 2.0$ & $1.338 \pm 0.281$ & $-\cdots$ & $\ldots$ \\
\hline 36 & -. & $\ldots$ & $87.7 \pm 4.8$ & $7.703 \pm 0.886$ & $52.6 \pm 1.6$ & $1.807 \pm 0.227$ & $141 \pm 6$ & $13.20 \pm 1.29$ \\
\hline 38 & $23.5 \pm 4.6$ & $-5.264 \pm 0.944$ & $88.0 \pm 2.7$ & $6.348 \pm 0.440$ & $54.4 \pm 5.3$ & $1.515 \pm 0.707$ & $143 \pm 18$ & $12.91 \pm 2.32$ \\
\hline 40 & $26.5 \pm 1.3$ & $-6.596 \pm 0.300$ & $140.2 \pm 5.9^{4}$ & $14.85 \mathrm{~K} \pm 0.981^{\mathrm{B}}$ & $52.7 \pm 1.7$ & $1.751 \pm 0.223$ & $141 \pm 11$ & $13.02 \pm 1.43$ \\
\hline Av & $24.2 \pm 1.6$ & $-5.073 \pm 0.370$ & $91.3 \pm 3.4$ & 0.575 & $52.9 \pm 2.2$ & $1.583 \pm 0.307$ & $142 \pm 11$ & $13.32 \pm 1.49$ \\
\hline
\end{tabular}

"Values not used in averaging.
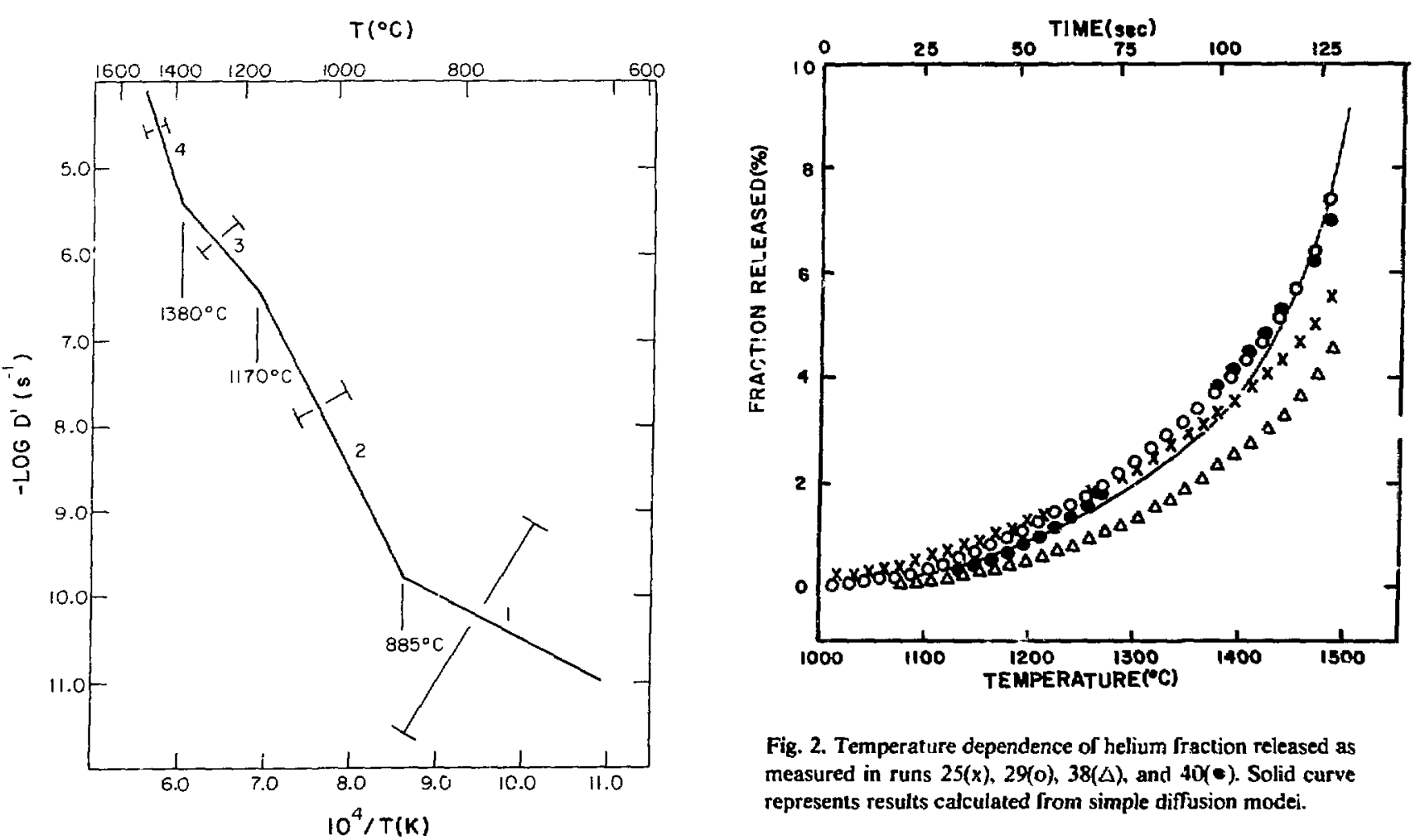

Fig. 2. Temperature dependence of helium fraction released as measured in runs $25(x), 29(0), 38(\Delta)$, and $40(\bullet)$. Solid curve represents results calculated from simple diffusion modei.

Fig. 1. Temperature dependence of effective diffusion coefli$-: \mathrm{nt}, \mathbf{D}^{\prime}$, for helium release from plutonia samples exposed to $227^{\circ} \mathrm{C} / \mathrm{min}$ ramp. 

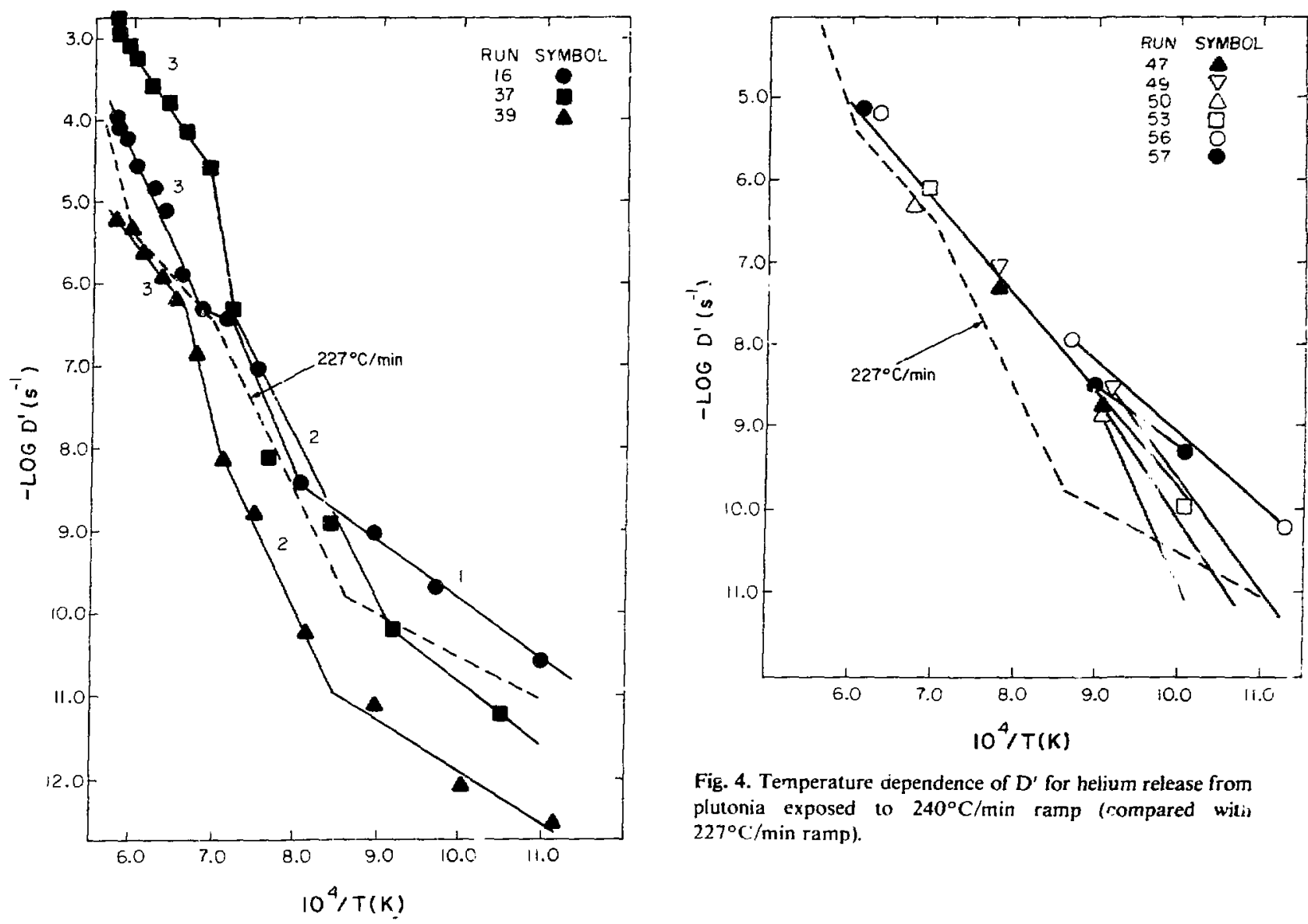

Fig. 4. Temperature dependence of $D^{\prime}$ for helium release from plutonia exposed to $240^{\circ} \mathrm{C} / \mathrm{min}$ ramp (compared witi) $227^{\circ} \mathrm{C} / \mathrm{min}$ ramp).

Fig. 3. Temperature dependence of $D^{\prime}$ for helium relcase from plutonia exposed to $454^{\circ} \mathrm{C} / \mathrm{min}$ ramp (compared with $227^{\circ} \mathrm{C} / \mathrm{min}$ ramp).

\begin{tabular}{|c|c|c|c|c|c|c|c|c|c|}
\hline \multirow{2}{*}{$\begin{array}{l}\text { Thermal } \\
\text { Ramp } \\
\left({ }^{3} \mathrm{C} / \mathrm{min}\right)\end{array}$} & \multirow{2}{*}{$\begin{array}{l}\text { Run } \\
\text { No. }\end{array}$} & \multicolumn{2}{|c|}{ Low Tempersture } & \multicolumn{2}{|c|}{ Medium Tempet ature } & \multicolumn{2}{|c|}{ Hiph Temperature } & \multicolumn{2}{|c|}{ Very ' ligh Temperature } \\
\hline & & E. & $\log \mathrm{D}_{5}$ & E. & $\log D_{3}$ & $\mathbf{E}_{1}$ & $\log \mathrm{D}_{0}^{\prime}$ & $E_{1}$ & $\log D_{2}$ \\
\hline \multirow[t]{3}{*}{454} & 16 & $35.3+1.5$ & $-5.187=0.358$ & - & $\cdots$ & $53.4 \pm 7.8$ & $1.80 \pm 1.291$ & $87.5 \pm 3.3$ & $7.112=0.472$ \\
\hline & 37 & .r & $\cdots$ & $113 \pm 16$ & $11.94 \times 2.68$ & $69.8 \pm 2.1$ & $6.005 \pm 0.291$ & $\ldots$ & $\ldots$ \\
\hline & 39 & $33.8 \pm 3.2$ & $-4.428 \pm 0.708$ & $114 \pm 12$ & $9.94 \div 2.05$ & $69.6 \pm 6.6$ & $3.680 \pm 0.903$ & $\cdots$ & $\cdots$ \\
\hline \multirow[t]{6}{*}{240} & 47 & $62.3+1.0$ & $3.267 \pm 0.249$ & $\ldots$ &. & $52.6 \pm 3.1$ & $1.622=0.549$ & $\cdots$ & $\cdots$ \\
\hline & 49 & $58.8 \pm 1.4$ & $3.062 \pm 0.319$ & $\cdots$ & $\cdot$ & $50.8=2.8$ & $1.636 \pm 0.495$ & $\cdots$ & $\cdot \cdot$ \\
\hline & 50 & $98.5 \pm 2.2$ & $10.553 \pm 0.505$ & $\cdots$ & $\cdots$ & $508 \pm 1.5$ & $1.221=0.250$ & $\cdots$ & .- \\
\hline & 53 & .. & $\cdots$ & $\cdots$ & $\cdots$ & $59.6 \pm 0.8$ & $2.254 \pm 0.142$ & $\cdots$ & .. \\
\hline & 56 & $39.1 \pm 1.4$ & $-0.612 \pm 0.316$ & $\cdots$ & $\cdots$ & $54.6 \pm 1.1$ & $2.357=0.181$ & $\cdots$ & .. \\
\hline & 57 & $32.8 \pm 5.4$ & $-2.114 \pm 1.128$ & $\cdots$ & $\cdots$ & $53.9 \pm 1.0$ & $2.061 \pm 0.164$ & $\cdots$ & - \\
\hline
\end{tabular}




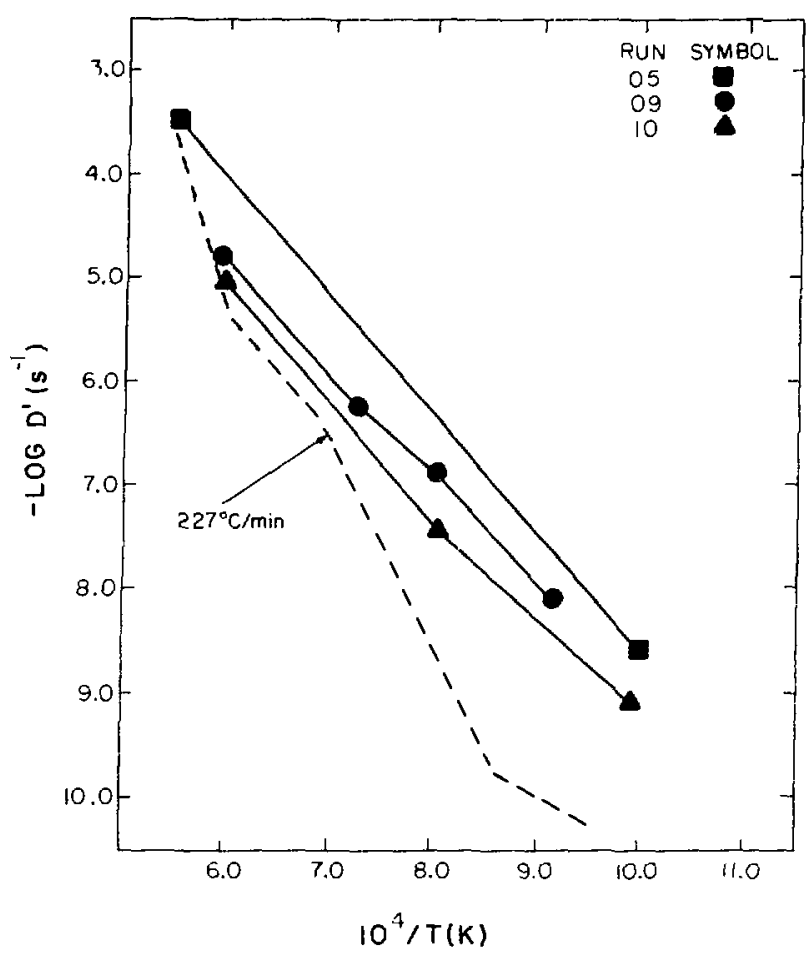

Fig. 5. Temperature dependence of $D^{\prime}$ for helium release from plutonia exposed to $148^{\circ} \mathrm{C} / \mathrm{min}$ ramp (compared with $227^{\circ} \mathrm{C} / \mathrm{min}$ ramp).

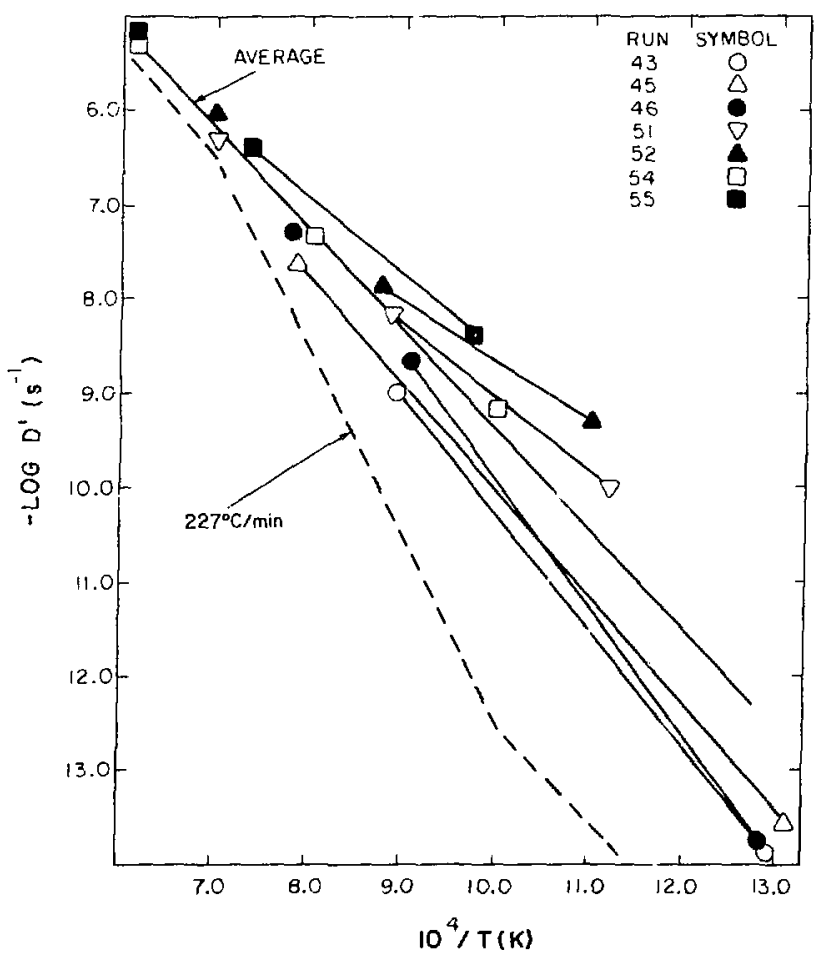

Fig. 6. Temperature dependence of $D^{\prime}$ for helium release from plutonia exposed to $122^{\circ} \mathrm{C} / \mathrm{min}$ ramp (compared with $227^{\circ} \mathrm{C} / \mathrm{min}$ ramp).

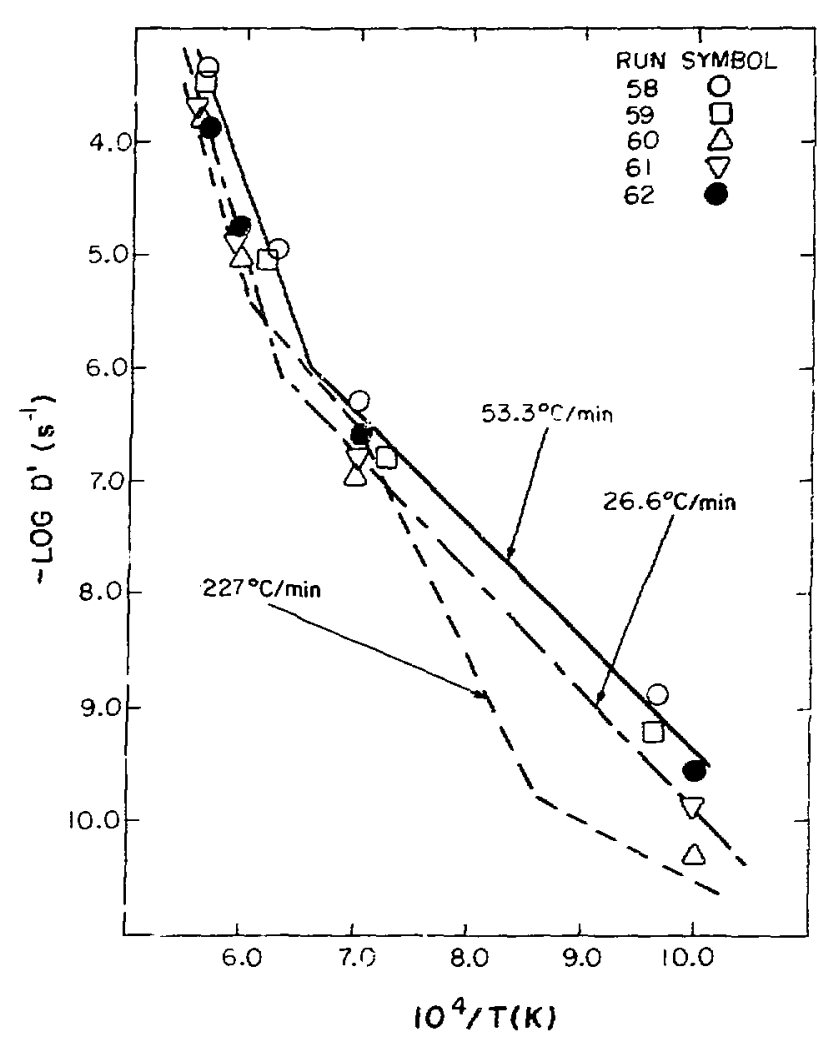

Fig. 7. Temperature dependence of $D^{\prime}$ for helium release from plutonia exposed to $53.3^{\circ} \mathrm{C} / \mathrm{min}$ ramp (runs 58,59 ) and $26.6^{\circ} \mathrm{C} / \mathrm{min}$ (runs $60-62$ ) compared with $227^{\circ} \mathrm{C} / \mathrm{min}$ ramp.

medium-temperature zones are not observable in most cases. The corresponding values of $\mathrm{E}_{\mathrm{a}}$ and $\log \mathrm{D}_{0}^{\prime}$ are listed in Table IV. Agreement of the high-temperature $E_{a}$ values are generally good, although there appears to be a trend toward decreasing magnitudes with siower pulse rates.

\section{Fuel Microstructures}

Samples were obtained from the center and from the outside edge of the fractured GPHS fuel pellet GP-19. One portion from each region was submitted to metallographic analysis, and the remaining fractions were subjected to thermal ramps during which the helium release rates were measured. Since the GP-19 pellet had been exposed earlier to a simulated reentry thermal pulse, some helium bubble growth in the grain boundaries was expected. The microstructure of a sampic removed from the pellet center is shown in Fig. 9a, an 3 no helium bubble growth is observable. The general onen porosity and variation in grain size are evidert. This is contrasted with 


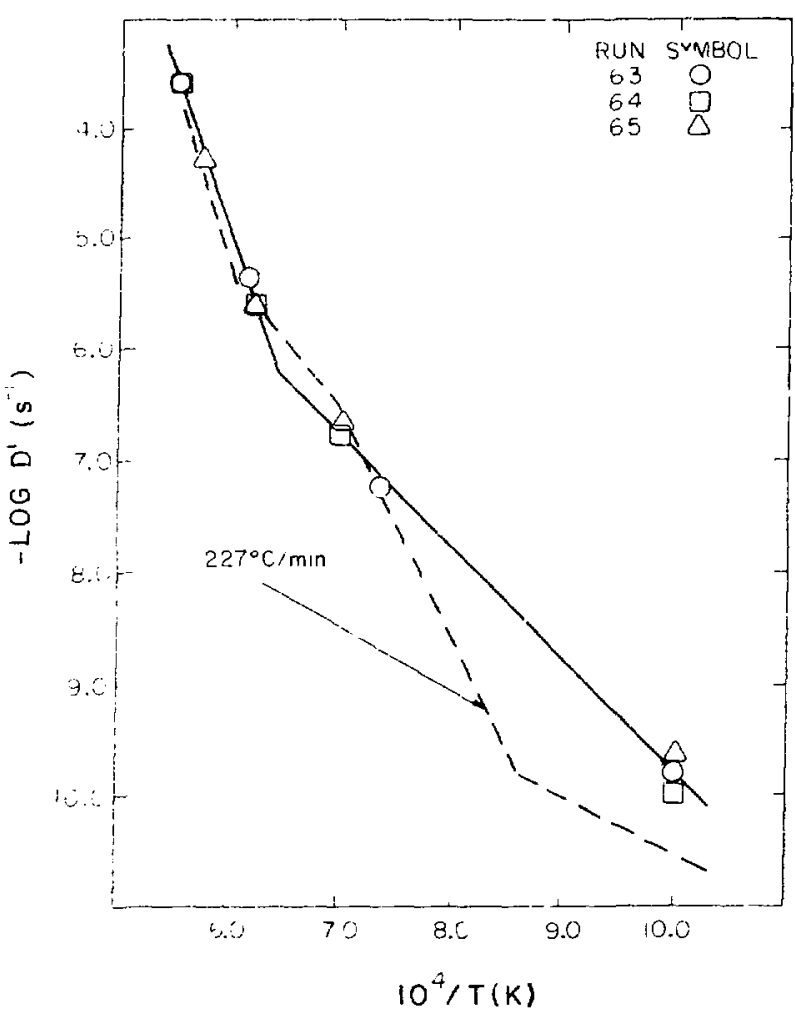

Fig. $8.1 \mathrm{cmpe}$ ature dependence of $\mathrm{D}^{\prime}$ for helium reledse from plutonia exposed to $12^{\circ} \mathrm{C} / \mathrm{min}$ ramp (compared with $227^{\circ} \mathrm{C} / \mathrm{min}$ ramp). the microstructure of the sample removed from the pellet edge shown in Fig. 9b. Severe telium damage is obvious with bubble strings evident along many of the grain boundaries. Following exposure of the eage pieces to thermal ramps of 227 and $454^{\circ} \mathrm{C} / \mathrm{min}$. most of the previous helium bubble damage annealed out. However, helium bubbles within the grain boundaries were observed near the outer surfaces of an edge sample exposed to the $227^{\circ} \mathrm{C} / \mathrm{min}$ ram? (Fig. 10a). This is contrasted with the edge sample exposed to the faster $454^{\circ} \mathrm{C} / \mathrm{min}$ pulse in which the helium bubbles appeared localized in the center of the sainple (Fig. 10b). Analogous thermal ramps of samples from the pellet center showed additional helium damage in both samples, especially in the case of the faster pulse.

The correlation between the microstructure and helium release rate is illustra.ed in Fig. 11 , Runs 36 and 37 were performed on samples taken $1 \mathrm{sm}$ the center of the fuel pellet. which had higher porosity and smaller average gain size than did samples from the edge of the pellet. These exposures were run at thermal ramps of 227 and $454^{\circ} \mathrm{C} / \mathrm{min}$. respectively. The sample exposed to the faster pulse should have experienced more grain boundary trapping of the helium. It is ar zarent that the magnitudes of the $D^{\prime}$ values ire appr ir.tately the same

TABLE IV. Activation Energies, $\mathrm{E}_{\mathrm{n}}$ (kcal), and $\log \mathrm{D}_{0}^{\prime}\left(\mathrm{s}^{\prime}\right)$ Values Obtained from Helium Release Analyses of ${ }^{23 \times} \mathrm{PuO}_{2}$ Samples Exposed to Thermal Ramps of $148.122,53.3,26.6$, and $12.0{ }^{\circ} \mathrm{C} / \mathrm{min}$

\begin{tabular}{|c|c|c|c|c|c|c|c|}
\hline \multirow{2}{*}{$\begin{array}{l}\text { Thermal } \\
\text { Ramp } \\
\left({ }^{\circ} \mathrm{C} / \mathrm{min}\right)\end{array}$} & \multirow{2}{*}{$\begin{array}{l}\text { Run } \\
\text { No. }\end{array}$} & \multicolumn{2}{|c|}{ Low Temperature } & \multicolumn{2}{|c|}{ High Temperature } & \multirow{2}{*}{$\begin{array}{c}\text { Very high } \\
\mathrm{E}_{\mathrm{B}}\end{array}$} & Temperature \\
\hline & & $\mathrm{E}_{\mathrm{a}}$ & $\log D_{0}^{\prime}$ & $E_{u}$ & $\log D_{0}^{\prime}$ & & $\log D_{0}$ \\
\hline \multirow[t]{3}{*}{148} & 5 & -. & $\cdots$ & $52.3 \pm 2.9$ & $2.851+0.046$ & $\cdots$ & \\
\hline & 9 & & $\ldots$ & $51.4 \div 1.5$ & $1.890 \pm 0.215$ & & \\
\hline & 10 & & -- & $53.2 \pm 0.6$ & $1.934+0.105$ & $\ldots$ & \\
\hline \multirow[t]{7}{*}{122} & 43 & $\cdots$ & $\cdots$ & $56.3 \pm 0.6$ & $2.015 \div 0.154$ & $\cdots$ & \\
\hline & 45 & $\ldots$ & $\ldots$ & $51.8 \pm 0.4$ & $1.276 \pm 0.082$ & & \\
\hline & 46 & $62.5 \pm 0.8$ & $3.740=0.194$ & $50.6 \pm 2.7$ & $1.391=0.486$ & $\cdots$ & \\
\hline & 51 & $.37 .3+1.3$ & $-0.877 \pm 0.295$ & $45.6 \pm 1.3$ & $0.689 \pm 0.218$ & $\cdots$ & \\
\hline & $\leq 2$ & $38.7+1.9$ & $-0.362 \pm 0.432$ & $48.2 \pm 2.2$ & $1.335 \pm 0.356$ & $\cdots$ & \\
\hline & 54 & $40.9+1.3$ & $-0.143 \pm 0.247$ & $49.5 \pm 0.9$ & $1.348 \pm 0.135$ & $\cdots$ & \\
\hline & 55 & $37.8 \pm 1.0$ & $-0.294 \pm 0.196$ & $47.6 \pm 1.6$ & $1.210 \pm 0.230$ & $\ldots$ & . \\
\hline \multirow[t]{2}{*}{$53 . j$} & 58 & $\ldots$ & $\ldots$ & $+5.7 \pm 0.5$ & $0.784 \pm 0.084$ & $123.1 \pm 2.9$ & $11.882: 0.372$ \\
\hline & 59 & $\ldots$ & $\ldots$ & $4.5 .6 \pm 0.3$ & $0.399+0.060$ & $127.6=2.9$ & $12.286=0.369$ \\
\hline 31.0 & 66 & $65.8+1.0$ & $5.067+0.121$ & $10.0 \pm 7.3$ & $-1.890=1.013$ & $76.1 \pm 4.2$ & $5.548=0.510$ \\
\hline \multirow[t]{3}{*}{26.6} & 60 & $\cdots$ & $\ldots$ & $51.3 \pm 0.3$ & $0.892: 0.051$ & $145.8 \pm 3.4$ & $13.964 \pm 0.432$ \\
\hline & 61 & . & .. & $46.5+0.3$ & $0.319=0.056$ & $150.0 \div 3.8$ & $14.531 \div 0.484$ \\
\hline & 62 & $\ldots$ & $\ldots$ & $45.1 \pm 0.3$ & $0.314,0.053$ & $149.2 \pm 5.1$ & $14.6 .30=0.65\}$ \\
\hline \multirow[t]{3}{*}{12.0} & 63 & $\cdots$ & .. & $44.5+0.2$ & $-0.073+0.03^{-}$ & $1.32 .0 \pm 1.0$ & $12.417=0.130$ \\
\hline & 64 & $\cdots$ & -. & $48.4+0.2$ & $0.660+0.045$ & $139.6 \neq 1.1$ & $13.335 \pm 0.138$ \\
\hline & 65 & $\ldots$ & $\ldots$ & $45.0 \pm 0.2$ & $0.223 \mp 0.040$ & $128.0 \pm 1.9$ & $11.744 \pm 0.250$ \\
\hline
\end{tabular}




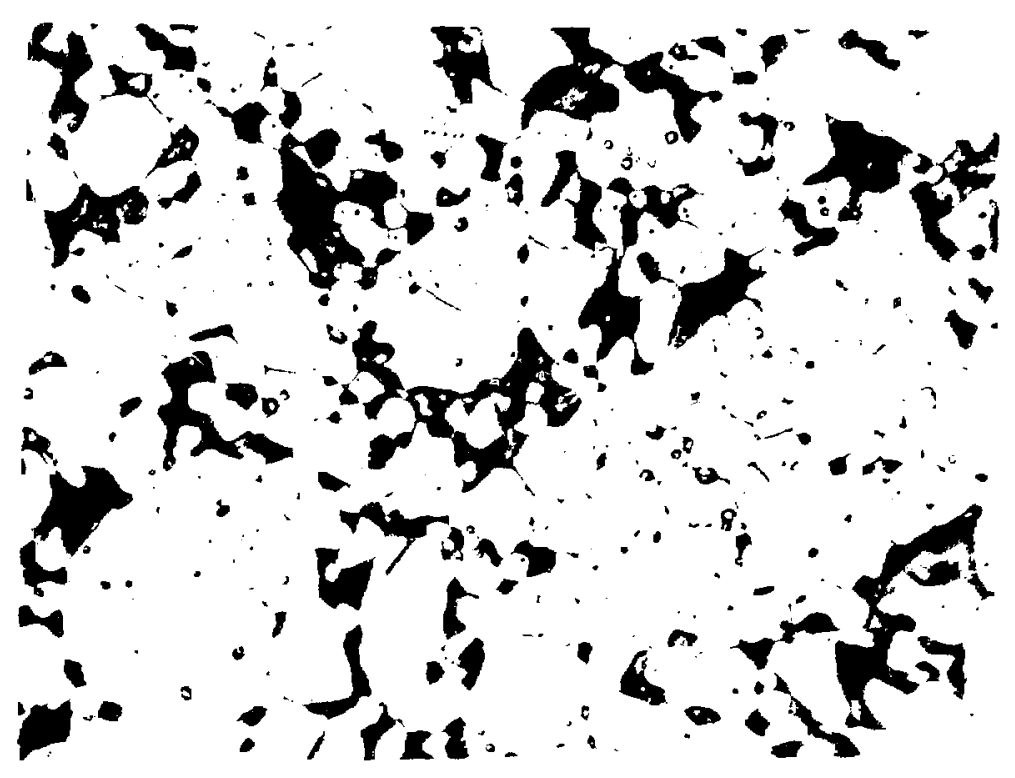

(a)

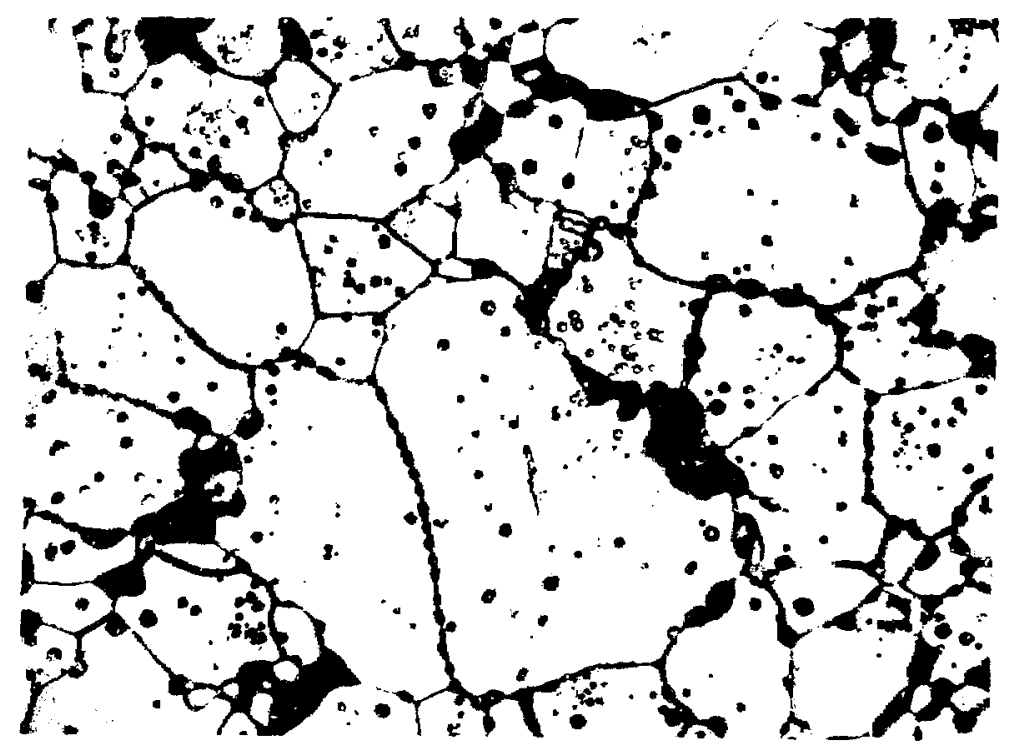

(b)

Fig. 9. (a) Micrastructure of sample removed from center of GP-19 pellet showing bubble growth ( $500 x$, AP). (b) Microstructure of edge GP-19 sample displaying extensive bubble growth ( $500 \mathrm{x}, A \mathrm{E})$. 


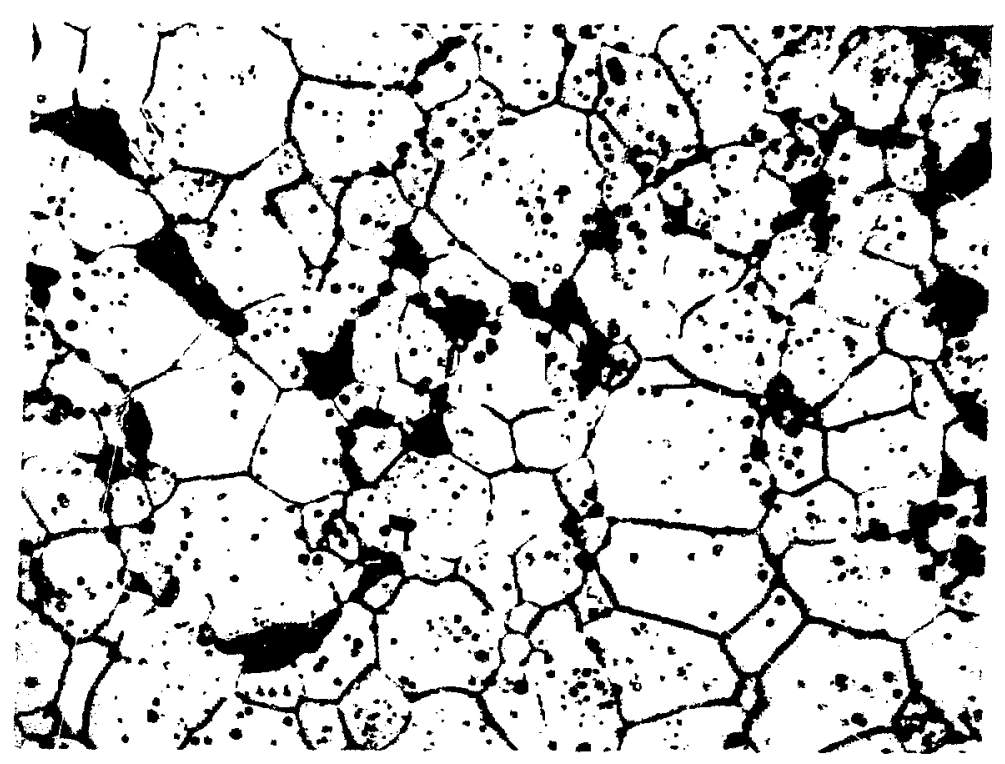

(a)

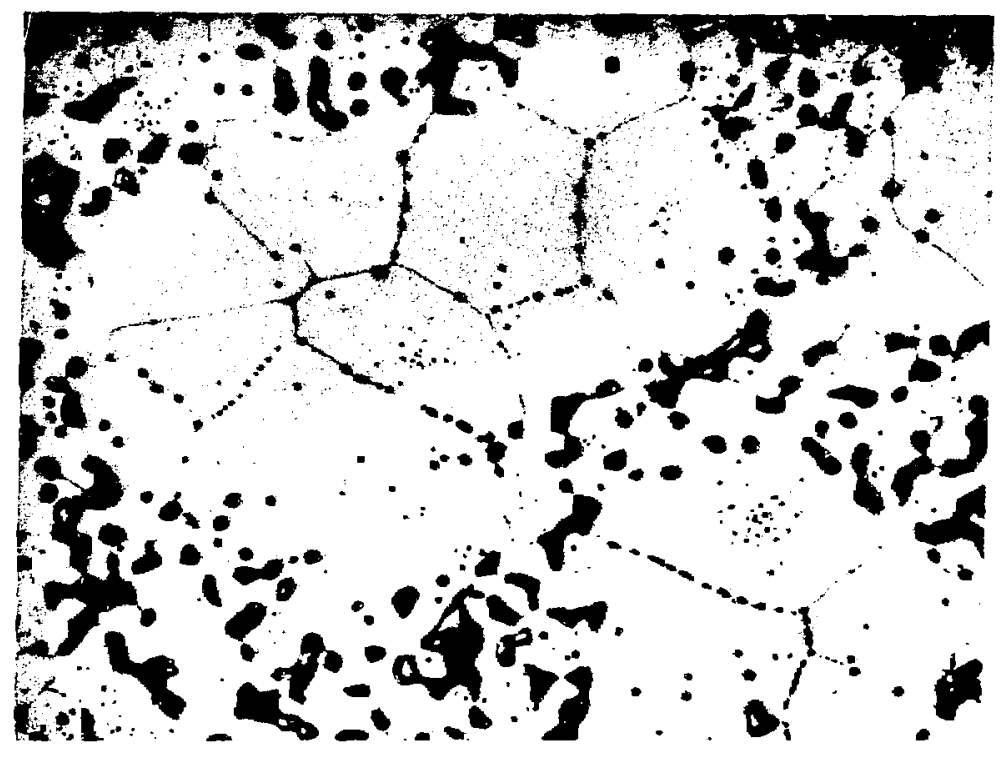

(b)

Fig. 10. (a) Microstructure of edge GP.J9 sample exposed to $227^{\circ} \mathrm{C} / \mathrm{min} \mathrm{ramp}$ showing bubbles near outer surface. (b) Microstructure of edge GP. 19 sample exposed to $454^{\circ} \mathrm{C} / \mathrm{min}$ ramp and showing extensive bubble growth. 


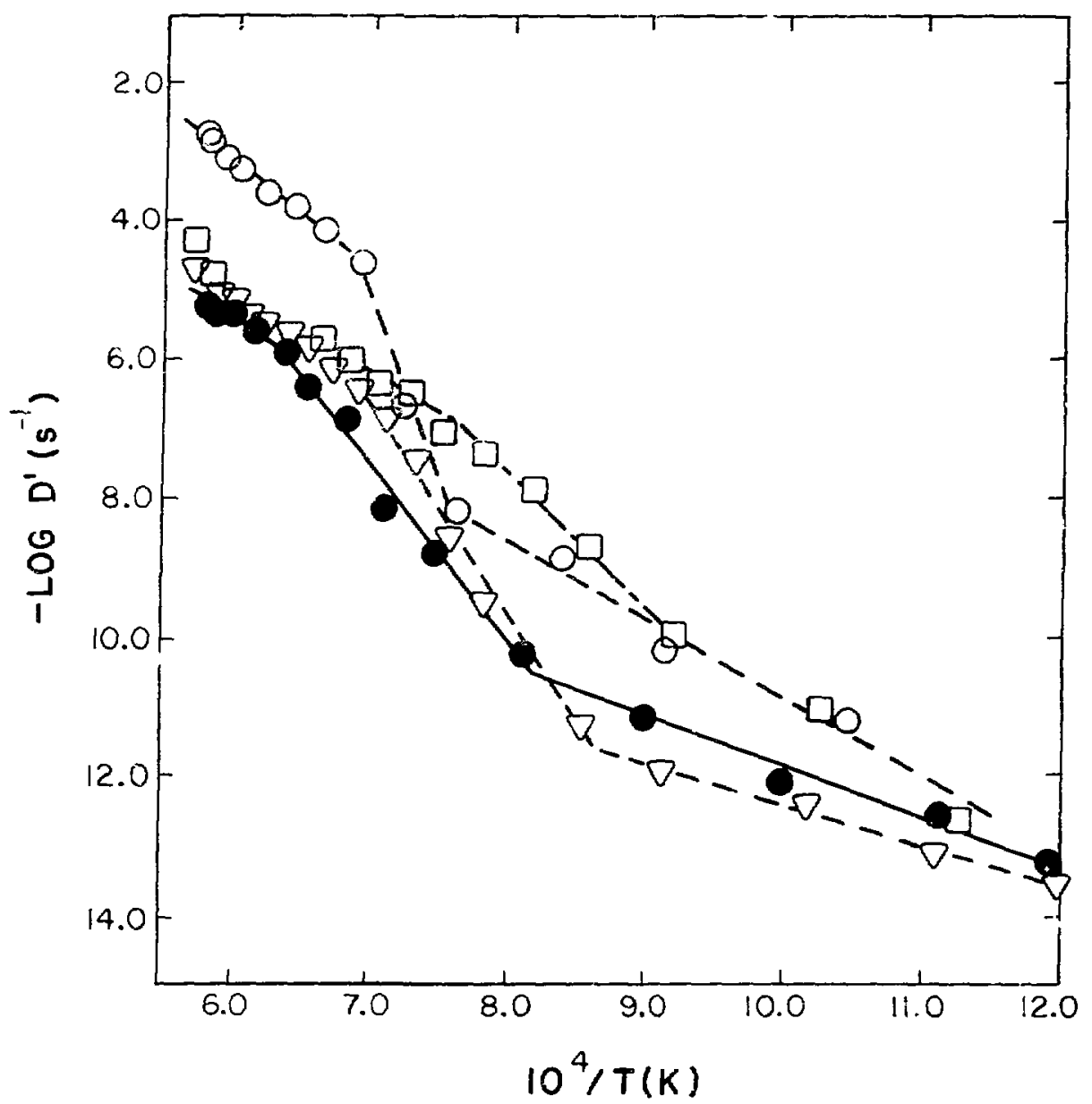

Fig. 11. Temperature dependence of $)^{\prime}$ from runs $36\left(\square\right.$, center, $\left.227^{\circ} \mathrm{C} / \mathrm{min}\right) .37\left(0\right.$, center, $\left.454^{\circ} \mathrm{C} / \mathrm{min}\right) .39$ (๑, outside, $\left.454^{\circ} \mathrm{C} / \mathrm{min}\right)$, and $40\left(\nabla\right.$, outside, $\left.227^{\circ} \mathrm{C} / \mathrm{min}\right)$.

at low temperatures. This is contrasted with the hightemperature region where the $D^{\prime}$ values increase much more rapidly in the crse of the faster pulse and finally attain significantly !igher values. Runs 39 and 40 were performed on samples removed from the outside edge, where the density was higher and the average grain size larger. Hence, we would expect lower $D^{\prime}$ values compared with the material from the center. This is indeed the case at low temperatures. However, as the temperature increased, the same magnitude and temperature dependence of $D^{\prime}$ were measured as in the previous run 36 . Note that the initial values of $D^{\prime}$ for the edge samples are almost two orders of magnitude lower than the values for the center samples between 1000 and $1100 \mathrm{~K}$. This is consistent with the microstructural differences. The thermal ramp had less effect on the edge samples, which is reasonable considering the more limited grain size distribution. (Because of the larger grains in the edge samples, there should be less grain boundary trapping.)

Helium release from the three 8.6-yr-old fuel pellets subjected to a thermal ramp of $10^{\circ} \mathrm{C} / \mathrm{min}$ is depicted in Fig. 12. Because of self-heating effects, the ambient temperature of the pellets in vacuum (determined to be $170^{\circ} \mathrm{C}$ ) was added to correct the temperatures measured with the graphite calibrant cell. The previously determined helium release behavior of an LWRHU containing an 8-yr-old pellet from the same batch is also shown. The results compare very favorably in terms of the magnitude and temperature dependence of $\mathrm{D}^{\prime}$. Figure 12 also shows the results from run 66 in which the SRL fuel 


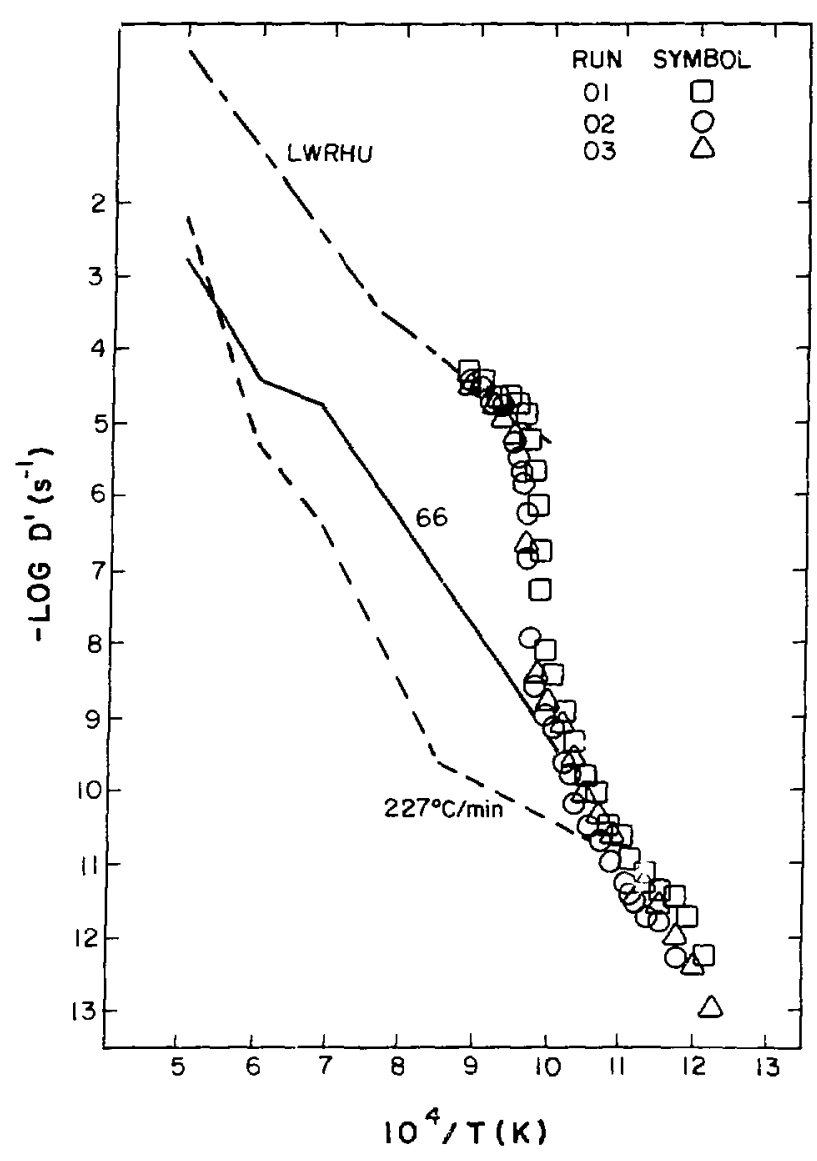

Fig. 12. Temperature dependence of $D^{\prime}$ for helium release from 8-yr-oid fuel (runs 1-3 compared with LWRHU capsule) and SRL pellet (run 66) compared with the $227^{\circ} \mathrm{C} / \mathrm{min}$ pulse.

sample was subjected to a thermal pulse of $31{ }^{\circ} \mathrm{C} / \mathrm{min}$. The corresponding average behavior of the GP-19 fuel exposed to the much faster $227^{\circ} \mathrm{C} / \mathrm{min}$ pulse is also shown for comparison. At low teinperatures, the $\mathrm{D}^{\prime}$ values appear to converge. It is interesting that the temperature dependence of the SRL-produced fuel is the same up to $1200^{\circ} \mathrm{C}$ as that of the 8.6 -yr-old pellets at lower temperatures.

The microstructures of the 8.6-yr-old and SRL pellets are shown in Fig. 13. The average grain sizes appear to be $\sim 12$ and $8 \mu \mathrm{m}$, respectively. These train sizes are significantly smaller than the largest GPHS grain sizes, which range up to $50 \mu \mathrm{m}$.

\section{DISCUSSION}

The helium release behavior of plutonia has been characterized in this study. The magnitudes and terrpera- ture dependences of the effective diffusion coefficients obtained by application of a simple diffusion model ase remarkably consistent and relatively independent of the thermal pulse above $1150^{\circ} \mathrm{C}$. At lower temperatures there appears to be a heating-rate dependence, which is believed due to grain size effects. It should be recognized that the simple diffusion model used to analyze the data is oniy an approximation since the effects of grain size and grain boundary trapping and diffusion as well as helium bubble growth and migration are not included in the treatment.

Correlation of tile helium release behavior at the various heating rates used in this study revealed the presence of four distinct regimes. These are depicted in an idealized plot of $\log D^{\prime}$ vs $1 / T$ (Fig. 14). The mechanisms postulated to explain these phenomena are based on these results as well as on previous observations of inert gas diffusing through fluorite lattices.

At fuel temperatures below $885^{\circ} \mathrm{C}$, the helium release is dominated by simple bulk diffusion through the grains with possible subsequent trapping of the gas along the grain boundaries. The rate of gas arriving at the grain boundaries appears to be higher than the diffusional rate along the boundaries for the case of fast pulses; hence. the helium tends to be trapped at these interfacial regions. Gaseous diffusion within the grains at these low temperatures is believed to be controlled by the movement of point defects such as dislocations and oxygen vacancies. In a series of isothermal studies by Ando, Oishi, and Hidaka ${ }^{11}$ on helium diffusing in thoria below $900^{\circ} \mathrm{C}$. they measured an $E_{\mathrm{a}}$ of $17.6 \pm 2.2 \mathrm{kcal}$, which compares favorably with the $24.2 \pm 1.6 \mathrm{kcal}$ measured in this study for helium in plutonia. Diffusional behavior over this region would be expected to be more susceptible to heating rates, grain sizes, and helium inventory since these can affect $t^{t}=$ ievel of trapping along the grain boundaries.

The second linear region, $885-1170^{\circ} \mathrm{C}$, represerts the formation and growth of bubbles along the grain boundares resuiting in an increased heliun release rate. In an anaiogous study over a similar temperature range. Cornell ${ }^{12}$ observed tha: the growth of xenon or krypton bubbles in urania has an $\mathrm{E}_{\mathrm{a}}$ of $91 \pm 14 \mathrm{kcal}$, which shows excellent agreement with the average value of $91.3 \pm 3.4$ kcal determined in this study for this region. The coalescence of bubbles along the grair boundaries ultimately leads to chains or tunnels along the grain boundaries through which the helium can migrate freely to the surface. At this point, the grain boundaries no longer serve as effective traps for the helium. 


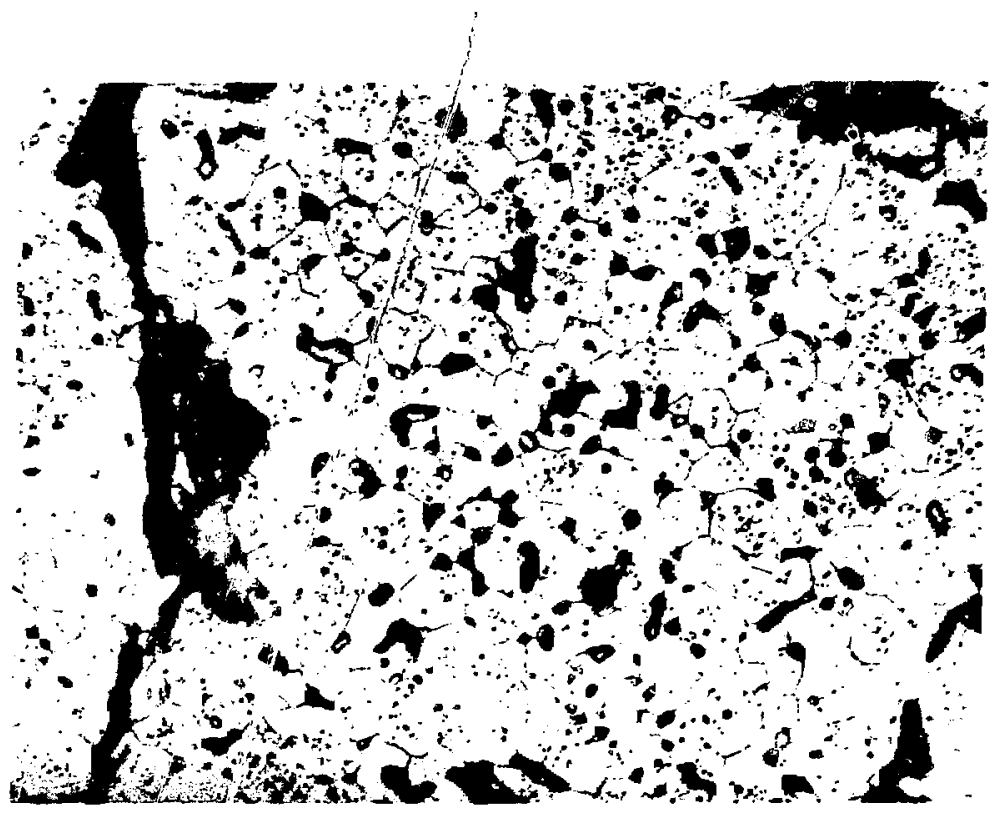

(a)

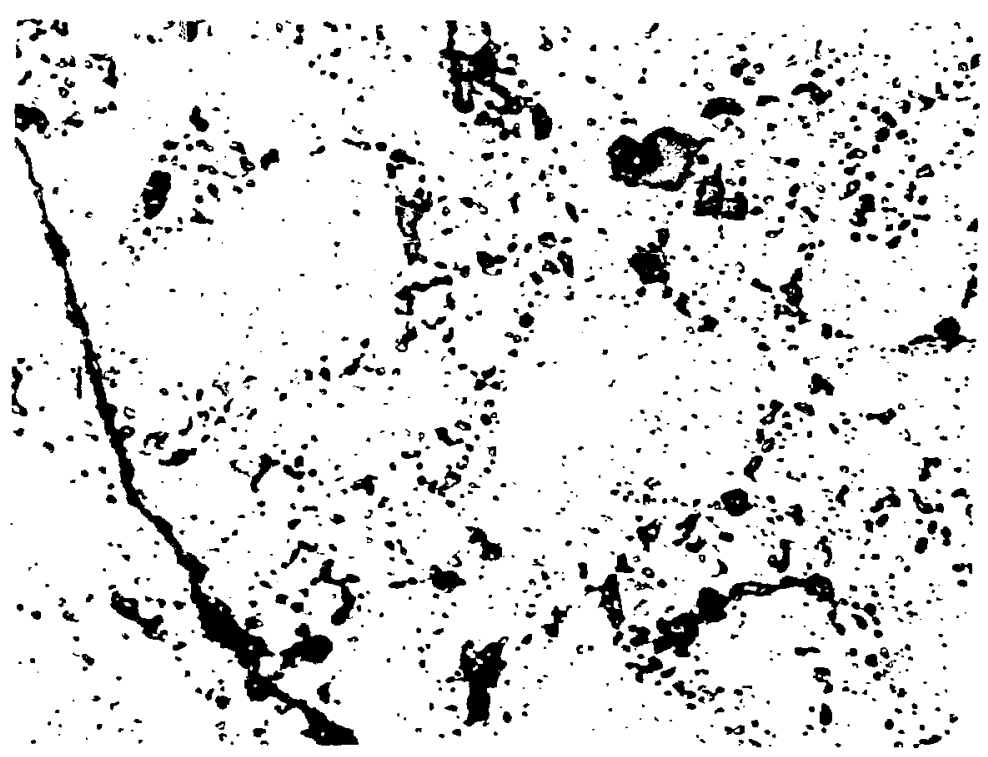

(b)

Fig. 13. (a) Microstructure of 8.6-yr-old fuel with average grain size of $12 \mu \mathrm{m}$. (b) Microstructure of SRL pellet 17914-1 with 8- $\mu \mathrm{m}$ grain size. 


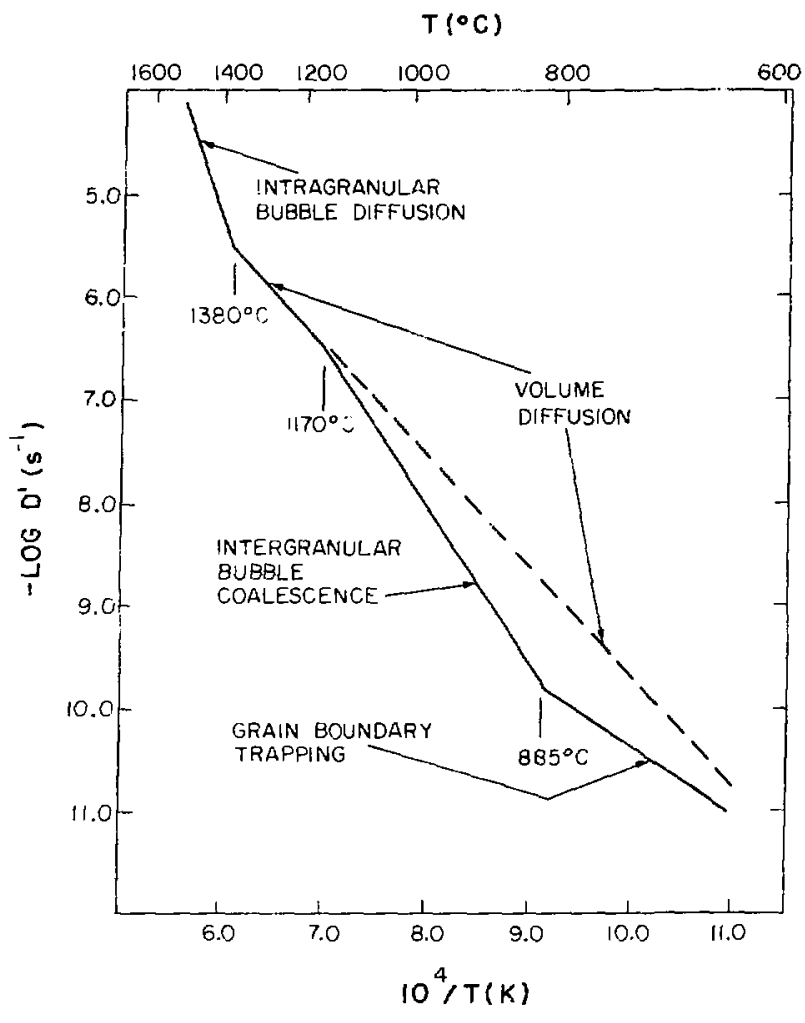

Fig. 14. Idealized plot of the temperature dependence of $D^{\prime}$ depicting regimes of mechanistic changes.

Between 1170 and $1380^{\circ} \mathrm{C}$, the helium release is determined by volume diffusion through the grains. Ando, Oishi, and Hidaka " observed for helium diffusing through thoria over this range that an $E_{a}$ of $49.9 \pm 1.4$ $\mathrm{kcal}$ is required. This value agrees well with the corresponding value of $52.9 \pm 2.2 \mathrm{kcal}$ measured in this study. They showed that the helium ciffusion over this temperature range is dependont upon the rate of oxygen diffusion through the thoria. A similar ciependence is probable ther ior helium diffusing in plutonia. This region dominated by volume diffusion can exterd down to much lower temperstures if helium trapping along the grain boundaries is minimize.1. This would be the case with very slow heating rates, small g:ain sizes, !ow densities, or single crystals.

The fourth repion, above $1380^{\circ} \mathrm{C}$, corresponds to the onset of mobility of helium buibles internal to the grains. This bubble migration results in a dramatic increase in the helium release rate. Gulden ${ }^{13}$ found oy electron microscupy that the migration of fission-gas bubbles in urania between 1400 and $1500^{\circ} \mathrm{C}$ has an $\mathrm{E}_{\mathrm{a}}$ of $130 \pm 25$ $\mathrm{kcal}$. She also concluded that the bubble mobility is controlled by the diffusion of uranium ions within the oxide lattice. This $E_{a}$ value is consistent with the $142 \pm 11$ kcal measured in this study over the same temperature range.

It appears obvious from the comparison of the microstructure and the helium release behavior that migrating helium atoms and bubbles can be trapped at structural defects such as dislocations, grain boundaries, interna! pores, and grain edges. These defects limit the movement of helium and iead to more intensive bubble growtil at these points. These conclusions are consistent with the results of Land's ${ }^{14}$ previous metallographic study of microstructural damage in plutonia caused by helium release. He found no helium bubble damage in samples stored at ambient temperature and $900^{\circ} \mathrm{C}$. Heat treatment at $1150^{\circ} \mathrm{C}$ for $24 \mathrm{~h}$ did produce fine bubbles in the grain boundaries. Heat treatment at $1150^{\circ} \mathrm{C}$ produced more extensive helium bubble formation along the grain boundaries. The sxtent of damage was greater in the highdensity, !arge-grain-size samples. McDornell, Sheehan, and Sisson ${ }^{15}$ similarly found that smali-graincd shards of ${ }^{238} \mathrm{PuO}_{2}$ resisted bubble formation to above $1500^{\circ} \mathrm{C}$. There is proportionally higher grain boundary volume with smaller grain sizes; hence, it woulö require more helium to saturate the boundaries in these cases. An increase in porcsity leads to more paths to the suriace and a higher internal void volime, so saturation of the boundaries is more difficult. With a lower helium inventory, a given fractional release results in less helium arriving at the grain boundaries, again making saturation more difficult. These microstructural effects account for the variations in the observed helium release rates and $\mathrm{E}_{\text {, }}$ values.

It appears reasonable that the size of the heliumreleasing unit, a, is physically related to the average grain size. If this is the case, then $D^{\prime}$ should decrease inversely with $a^{2}$, but the grain size would have no effect on th: $E_{a}$ value. This size dependence would be less pronounced at the higher temperaiures as the smallei grains are depleted of their inventories. This phenomenon explains the observed variations in the $D^{\prime}$ values while essentially the same $E_{a}$ values are maintained over given temperature ranges.

Comparison of the results of this study with previcus measurements of helium diffusing through $\mathrm{P}_{1} \mathrm{O}_{2}$ is encouraging. Figure 15 shows the plot of $\log D^{\prime}$ vs $1 / T$ obtained in this study with the $227^{\circ} \mathrm{C} / \mathrm{min}$ ramp along with results from previous work. Angelini and coworker: ${ }^{15}$ measured helium release rates from ${ }^{238} \mathrm{PuO}_{2}$ microspheres in both isothermal and transient heating 


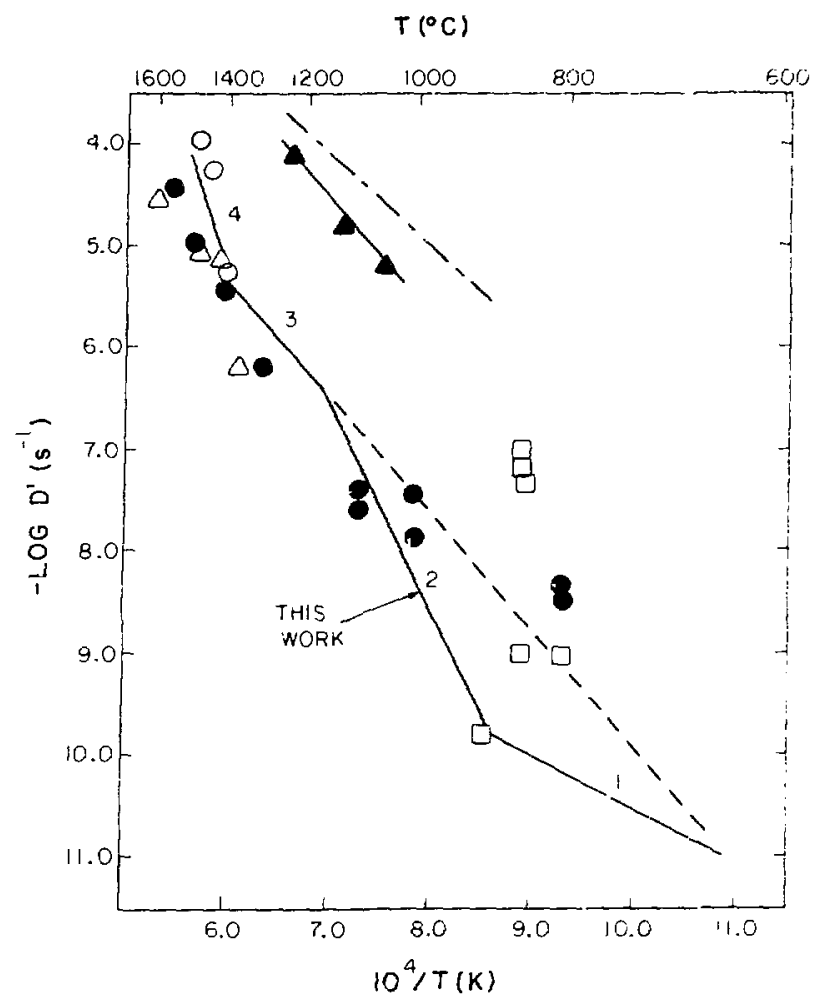

Fig. 15. Temperature dependence of $D^{\prime}$ nbtained from thermal pulse studies of microspheres: transient (-, Rer. 16): isothermal ( $\bullet$, Ref. 16), (A. Ref. 17); pellets: isothermal ( $\triangle .0$. Ref. 18); molybdenum cermets-isothermal ( $\square$. Rer. 19) compared with $227^{\circ} \mathrm{C} / \mathrm{min}$ ramp.

experiments. In the isothermal studies, they observed a break at $\sim 1160^{\circ} \mathrm{C}$. The low- and high-temperature regions had $E_{\mathrm{a}}$ values of 17.9 and $86.8 \mathrm{kcal}$, respectively. Since three types of microspheres with differing particle sizes as well as vacuum and argon atmospheres were used, it is difficult to estimate the errors in the measurements, but: the good agreement between the mr.gnitude of $D^{\prime}$ values measured during his isothermal study and duririg the current work is impressive. However, the $\mathrm{D}^{\prime}$ values from the transient-heating experiments are two order's of magnitude higher thail the corresponding values from this study. The $E_{a}$ value of $41.8 \mathrm{kcal}$ obtained from the transient-heating measurements correlates reasonably well with the $E_{a}$ measured in this study for volume diffusion over the same temperature range.

Mulford and Mueller ${ }^{37}$ performed measurements of the isothermal helium release rates for cylindrical pellets and microspheres of ${ }^{238} \mathrm{PuO}_{2}$. They found that the helium release rates from the microspheres were considerably higher than those from the pellets; however, the temperature dependence appears to correspond to the region dominated by volumic diffusion in the current work. The $D^{\prime}$ values for the pellets are slightly lower than the corresponding "alues obtained in the current work, but this is expected because of the differences in microstructures and techniques.

Mueller, Rohr, and Mulford ${ }^{18}$ performed further helium release measurements during isothermal heat treatments of ${ }^{238} \mathrm{PuO}_{2}$ pellets. The $\mathrm{D}^{\prime}$ values agree well with the corresponding levels measured for the wery high temperature region in the current work. They observed upon examining the microstructures of the samples following the heat treatments that the helium bubbles along the grain boundaries had coalesced, often resulting in formation of large bubbles and extensive strings. This observation is consistent with the mechanistic interpretation of bubble mobility above $1300^{\circ} \mathrm{C}$. Mueller, Rohr, Land, and Mulford ${ }^{19}$ also performed helium, iclease measurements on ${ }^{238} \mathrm{PuO}_{2}-\mathrm{Mo}$ cermets. It is interesting that several of the $\mathrm{D}^{r}$ values agree relatively well with the present work. They observed that the helium often was given off in bursts. which were difficult to model and which resulted in higher $D^{\prime}$ values. Johnson ${ }^{20}$ at Mound Facility also performed helium release measurements on GPHS fuel assemblies during heat treatment of the modules. Under isothermal conditions of $1410 \mathrm{~K}$, he obtained a value of $\log D^{\prime}\left(\mathrm{s}^{-1}\right)$ of -7.66 , which shows r. 'snable agreement with the corresponding value obin this study.

ere have been many studies of the diffusion of in gases xenon and krypton as well as of helium through $\mathrm{UO}_{2}$. Lawrence ${ }^{21}$ reviewed the results of many of these studies and found wide variations in the diffusion constants and $\mathrm{E}_{\mathrm{a}}$ values. One might expect $\mathrm{ThO}_{2}, \mathrm{UO}_{2}$, and $\mathrm{PuO}_{2}$ to have sirnilar diffusive behavior because of their common fluor ite crystal structure. Rufeh, Olander, and Pigford ${ }^{22}$ measured the diffusion rate of helium througi. $\mathrm{UO}_{2}$. Using their average particle size of $4 \mu \mathrm{m}$ as representing the size of the releasing unit, one obtains a $\log \mathrm{D}^{\prime}$ of -6.03 at $1200^{\circ} \mathrm{C}$, which agrees well with the corresponding $\mathrm{D}^{\prime}$ for $\mathrm{PuO}_{2}$. Matze $\mathrm{M}^{23}$ also observed that radon diffuses in $\alpha-\mathrm{Al}_{2} \mathrm{O}_{3}$ by two different mechanisms with $E_{a}$ values of 21 anc us kcal, respectively. The hightemperature value compares favorably with the energy $\sim 85 \mathrm{kcal}$ for self-diffusion of aluminum in slumina.

The diffusional parameters measured in the current study of helium in plutonia can be applied to predict the release behavior of fuel used in radioisotopic heat 
sources. The worst possible thermal ramp (AP2737) associated with atmospheric reentry of an LWRHU was calculated at Applied Physics Laboratory. The diffusion rate of helium within an LWRHU pellet exposed to such a reentry ramp was calculated based on the results of this study. The time and temperature dependence of the fractional release of helium is shown in Fig. 16. The total fractional release as well as the release rate is lower than was experimentally measured for LWRHU capsules containing fuel pellets $>8 \mathrm{yr}$ old. ${ }^{3}$ This difference is supported by the current study, which verified that the age and microstructure of the older fuel led to significantly higher release rates at high temperatures than do the age and microstruciure of the currently used heat source fuel.

To predict the helium fraction released from plutonia as a function of time and temperature for any thermal pulse, we wrote a program for a Hewlett-Packard* HP-87 computer. The basic code given in the appendix allows input of activation energies and $\log \mathrm{D}_{\mathrm{r}}^{\prime}$ values over selected temperature intervals to calculate the helium fractions released as a function of time and temperature.

This study has resolved many of the problems associated with previous helium release measurements. Since the helium release rate from plutonia was dependent upon heating rates as well as on fuel temperaiures and microstructures, it is not surprising that various samples showed very different diffusional behavior. The good agreement obtained by correlation with other observations of fission gases diffusing within fluorite lattices supports the mechanism proposed in this study.

It has now been firmly established that helium can be trapped within grain boundaries of plutonia exposed to fast heating rates. It follows that more extensive bubble formation would result from exposure to fast heating ramps, whereas very slow heating rates could result in no bubble formation along the grain boundaries. By using fuel with very small grain sizes or lower densities, trapping of the helium within the boundaries should also be minimized by the increased paths to the surface. In this case, a larger fraction of the helium would be released at lewer telıperatures. Dopants that increase the diffusion rate of the oxygen ions while retarding the diffusion rate of the plutonium ion should also be beneficial in leveling out the release over a larger temperature range.

*Hewlett-Packard Company, 1501 Page Mill Rd., Palo Alto, CA 94304.

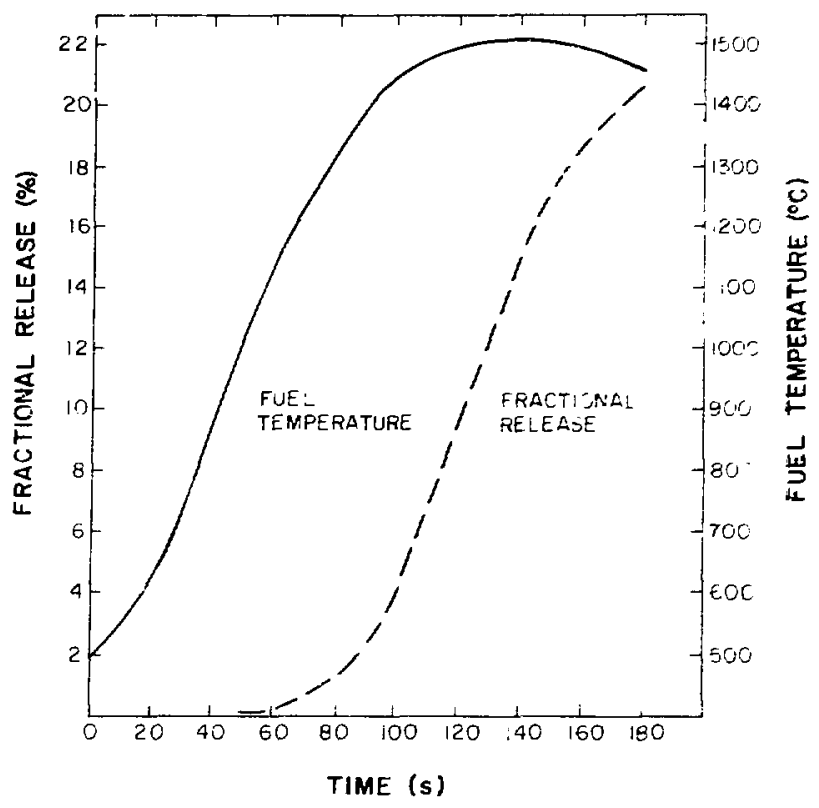

Fig. 16. Time dependence of the Applied Physics Laboratory calculated reentry ramp (AP2737) and the fractional release predicted from a simple diffusion model based on the results of this study.

It would be very valuable to develop a comprehensive mathematical model that includes the effects of trapping along grain boundaries as well as intergranular bubble movement. Such a theoretical approach would provide quantitative predictions of the influence of various fuel forms or heating rates upon the helium release behavior.

\section{REFERENCES}

1. R. E. Tate, "The Lightweight Radioisotope Heater Unit (LWRHU): A Technical Description of the Reference Design," Los Aiamos National Laboratory report LA-9078-MS (January 1982).

2. D. E. Peterson and C. E. Frantz, "Reentry Thermal Testing of a General Purpose Heat Source Fueled Clad," Los Alamos National Laboratory report LA-9227 (March 1982).

3. D. E. Peterson and J. S. Starzynski, "Reentry Thermal Testing of Light-Weight Radioisotopic Heater Units," Los Alamos National Laboratory report LA-9226 (March 1982). 
4. R. A. Kent, "LASL Fabrication Flow Sheet for GPHS Fuel Pellets," Los Alamos Scientific Laboratory report LA-7972-MS (September 1979).

5. J. W. Early and R. M. Abernathey, "Apparatus for Dynamic Measurements of Gases Released from Materials Heated Under Programmed TemperatureTime Control," Los Alamos National Laboratory report LA-9298-MS (April 1982).

6. R. M. Barrer, Diffusion In and Through Solids (Cambridge University Press, New York, 1951).

7. J. Crank, The Mathematics of Diffusion (Oxford University Press, New York, 1967).

8. P. Sung and J. Turnbauch, "Calculation of Diffusivity and Solubility with Error Analysis for Diffusion in a Sphere," J. Appl. Phys. 39, 346 (1968).

9. L. G. Kelly, Handbook of Numerical Methods and Applications (Addison-Wesley Publishing Co., Inc., Reading, Mass., 1967), p. 90.

10. P. Shewmon, "Atomic Theory of Diffusion," in Diffusion in Solids (McGraw-Hill Book Co., New York, 1963), Chap. 2.

11. K. Ando, Y. Oisji, and Y. Hadaka, "Self-Diffusion of Oxygen in Single Crystâl Thorium Oxide," j. Chem. Phys. 65 (7), 2751-5 (1976).

12. R. M. Cornell, "The Growth of Fission Gas Bubbles in Irradiated Uranium Dioxide," Phil. Mag. 19 (159), 539-54 (1968).

13. M. E. Gulden, "Migration of Gas Butbles in Irradiated Uranium Dioxide," J. Nucl. Mat. 23, 30-6 (1967).

14. C. C. Land, "Microstructural Danage Produced by Helium in Aged ${ }^{238} \mathrm{PuO}_{2}$ Fuels," Los Alamos Scientific Laboratory repori LA-8083 (January 1980).
15. W. R. McDonell, J. E. Sheehan, and R. D. Sission, "Helium Bubbles at Grain Boundaries of High Density ${ }^{238} \mathrm{PuO}_{2}$ Shards," Trans. Amer. Nucl. Soc. 22 , 214 (1975).

16. P. Angelini, R. E. McHenry, J. L. Scoit, W. S. Ernst, Jr., and J. W. Prados, "Helium Release from ${ }^{238} \mathrm{PuO}_{2}$ Microspheres." Oak Ridge National Laboratory report ORNL-4507 (March 1970).

17. R. N. R. Mulford and B. A. Mueller."Measurements of Helium Release from Materials Containing ${ }^{238} \mathrm{PuO}_{2}$," Los Alamos Scientific Laboratory report LA-5215 (July 1973).

18. B. A. Mueller, D. L. Rohr, and R. N. R. Mulford. "Helium Release and Microstructural Changes in ${ }^{238} \mathrm{PuO}_{2}$," Los Alamos Scientific Laboratory report LA-5524 (April 1974).

19. B. A. Muelles, D. L. Rúhr, C. C. Land, and R. N. R. Mulford, "Helium Release of ${ }^{238}$ Plutonia-Molybdenum Cermet Fuel," Los Alamos Scientific Laboratory report LA-5820. (March 1975).

20. E. W. Johnson, "Preliminary Helium Release Results," Mound Facility, Dayton, Ohio, Letter to D. E. Peterson (Dec. 18, 1981).

21. G. T. Lawrence, "A Review of the Diffusion Coefficient of Fission-Product Rare Gases in Uranium Dioxide," J. Nucl. Mat. 71, 195-218 (1978).

22. F. Rufeh, D. R. Olander, and T. H. Pigford. "The Solubility of Helium in Uranium Dioxide," Nucl. Sci. and Engin. 23, 335-8 (1965).

23. H. Matzke, "Rare-Gas Mobility in Some Anisotropic Ceramic Oxides: $\mathrm{Al}_{2} \mathrm{O}_{3}, \mathrm{Cr}_{2} \mathrm{O}_{3}, \mathrm{Fe}_{2} \mathrm{O}_{3}$. $\mathrm{U}_{3} \mathrm{O}_{8}$,' J. Mater. Sci. 2, 444-56 (1967). 


\section{APPENDIX}

Computer Program to Calculate Helium Fractions Released as a Function of Time and Temperature for any Given Thermal Ramp.

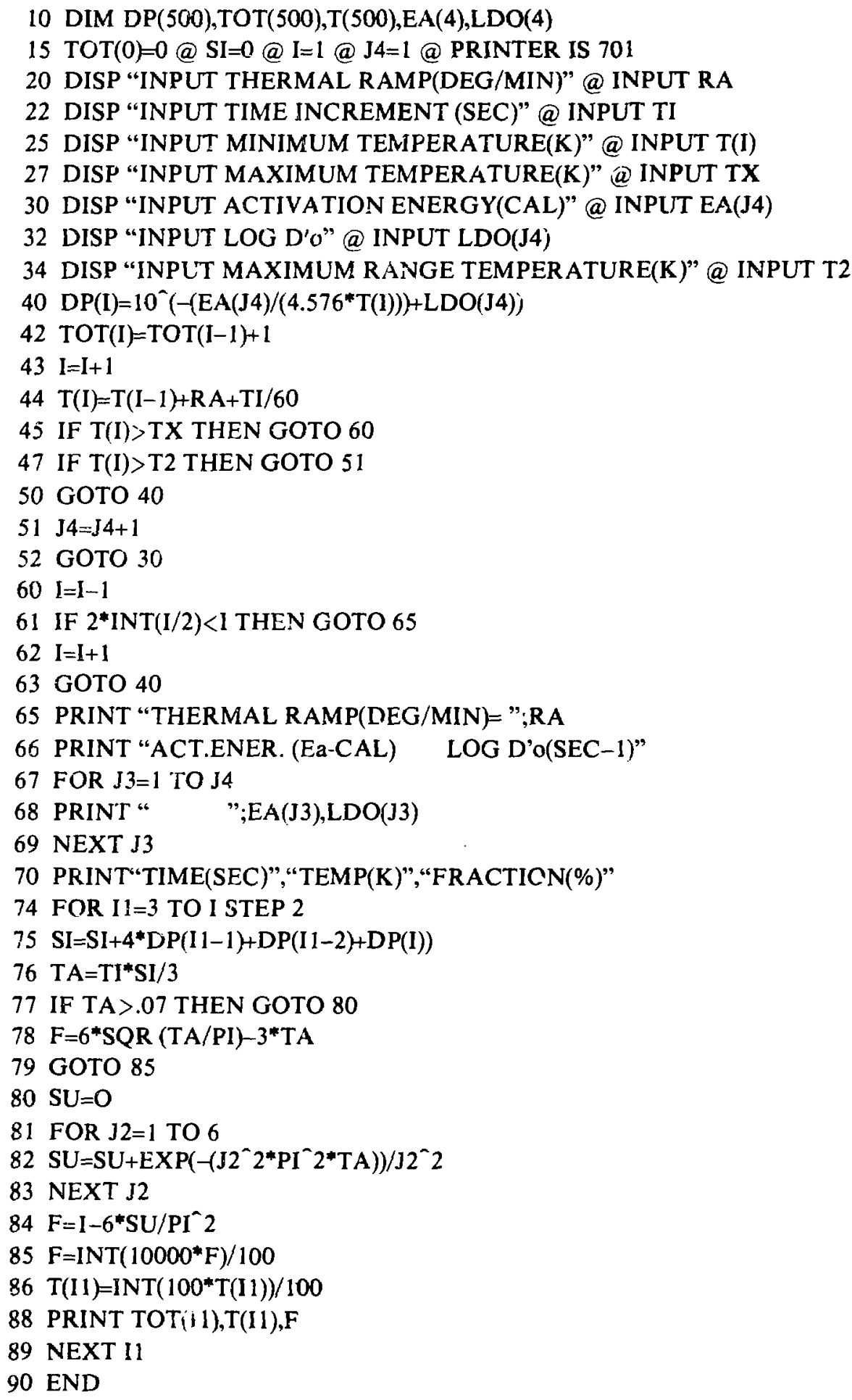

